\title{
A Technical Evaluation, Performance Analysis and Risk Assessment of Multiple Novel Oxy-Turbine Power Cycles with Complete $\mathrm{CO}_{2}$ Capture
}

\author{
Fernando Climent Barbaa , Guillermo Martínez-Denegri Sánchez ${ }^{a}$ Blanca Soler Seguía, \\ Hamidreza G. Darabkhani ${ }^{\mathrm{a}, *}$ and Edward J. Anthony ${ }^{\mathrm{a}}$ \\ ${ }^{a}$ Centre for Combustion and CCS, Energy Department, School of Water, Energy and Environment (SWEE), \\ Cranfield University, Cranfield, Bedfordshire, MK43 OAL, UK \\ *Corresponding Author: h.g.darabkhani@cranfield.ac.uk
}

\begin{abstract}
In recent years there has been growing concern about greenhouse gas emissions (particularly $\mathrm{CO}_{2}$ emissions) and global warming. Oxyfuel combustion is one of the key technologies for tackling $\mathrm{CO}_{2}$ emissions in the power industry and reducing their contribution to global warming. The technology involves burning fuel with high-purity oxygen to generate mainly $\mathrm{CO}_{2}$ and steam, enabling easy $\mathrm{CO}_{2}$ separation from the flue gases by steam condensation. In fact, $100 \% \mathrm{CO}_{2}$ capture and near-zero $\mathrm{NO}_{x}$ emissions can be achieved with this technology.

This study examines nineteen different oxy-turbine cycles, identifying the main parameters regarding their operation and development. It also analyses the use of advanced natural gas combustion cycles from the point of view of the carbon capture and storage (CCS) and considering political, legislative and social aspects of deploying this technology. Six oxy-turbine cycles which are at the most advanced stages of development (NetPower, CES, Modified Graz, E-MATIANT, AZEP100\% and SCOC-CC), were chosen to conduct a Political, Environmental, Social, Technological, Legislative and Economic (PESTLE) risk analysis. This compares each technology with a conventional combined cycle gas turbine (CCGT) power plant without carbon capture as the base-case scenario. Overall, the net efficiency of the different oxy-turbine cycles ranges between $43.6 \%$ and $65 \%$, comparable to a CCGT power plant, while providing the extra benefits of $\mathrm{CO}_{2}$ capture and lower emissions.
\end{abstract}

A multi-criteria analysis carried out using DECERNS (Decision Evaluation in Complex Risk Network Systems) software determined that, depending on the specific criterion considered, one can draw different conclusions. However, in terms of technology, environment and social opinion, the most promising cycles are the NetPower and CES cycles, whereas from an economic point of view, E-MATIANT is more competitive in the energy market. Giving each factor equal importance, the NetPower cycle must be considered to be the best oxy-turbine cycle based on our analysis.

Most of the oxy-turbine cycles are still under development and only a few cycles (e.g., CES and NetPower) are progressing to the demonstration phase. In consequence, political measures such as $\mathrm{CO}_{2}$ tax and emission allowances need to be implemented for oxy-turbine technologies to become the preferred option for fossil fuel power plants burning natural gas.

Key Words: Carbon capture and storage, oxy-turbine power cycle, air separation unit, combined cycle gas turbine, techno-economic analysis, PESTLE risk analysis 


\begin{tabular}{|ll|}
\hline Abbreviations \\
AHPS & Advanced oxy-fuel Hybrid Power System \\
ASU & Air Separation Unit \\
CCGT & Combined Cycle Gas Turbine \\
CCS & Carbon Capture and Storage \\
CES & Clean Energy Systems \\
COE & Cost of Electricity \\
CAPEX & Capital Expenditure \\
CPU & Compression and Purification Unit \\
DECERNS & Decision Evaluation in Complex Risk Network Systems \\
HICES & Hybrid and Improved CES cycle \\
HRSG & Heat Recovery Steam Generator \\
HTT & High-Temperature Turbine \\
IGCC & Integrated Gasification Combined Cycle \\
ITM & lon Transfer Membrane \\
LCA & Life Cycle Assessment \\
MCDA & Multi-Criteria Decision Analysis \\
PESTLE & Political, Environmental, Social, Technological, Legislative and Economic risk analysis \\
ROC & Renewable Obligation Certificate \\
SCOC-CC & Semi-Closed Oxy-fuel Combustion Combined Cycle \\
STHS & Solar Thermal Hybrid H 2 turbine power generation System \\
TRA & Technology Readiness Assessment \\
\hline
\end{tabular}

\section{Introduction}

Greenhouse gas emissions from the use of fossil fuels in power generation are a major environmental problem due to their contribution to global warming. In 2013, $\mathrm{CO}_{2}$ emissions represented $82 \%$ of greenhouse gas emissions in the UK and $39 \%$ of these $\mathrm{CO}_{2}$ emissions were produced by the energy supply sector [1]. The use of fossil fuels is expected to continue because of their availability and economic importance. As such, technologies such as carbon capture and storage (CCS) are fundamental in reducing the severity of the greenhouse effect [2].

Oxyfuel is a promising technology for power generation with carbon capture. It consists of burning fuel with high-purity oxygen at near-stoichiometric conditions and uses flue gas recirculation $(a+b)$ to control the combustor temperature. The process follows the global reaction shown in Equation 1. 


$$
\mathrm{CH}_{4}+2 \mathrm{O}_{2}+a \cdot \mathrm{CO}_{2}+b \cdot \mathrm{H}_{2} \mathrm{O} \rightarrow(1+a) \cdot \mathrm{CO}_{2}+(2+b) \cdot \mathrm{H}_{2} \mathrm{O}
$$

where $a$ is recirculated $\mathrm{CO}_{2}(\mathrm{~mol})$ and $b$ is recirculated $\mathrm{H}_{2} \mathrm{O}$ (mol)

The flue gases contain mainly $\mathrm{CO}_{2}$ and steam (and low proportions of $\mathrm{NO}_{x}, \mathrm{SO}_{x}, \mathrm{CO}$ ) which can be separated by condensation of the steam [3]. Subsequently, the steam-depleted stream is normally treated to obtain high-purity $\mathrm{CO}_{2}$ for further applications.

The advantages of this technology are near elimination of $\mathrm{NO}_{x}$ by avoiding the ingress of nitrogen into the burner, and the simplicity of the $\mathrm{CO}_{2}$ sequestration process compared to other techniques since the flue gases contain few impurities. On the other hand, the technology's drawbacks are the energy penalty caused by the requirement of high-purity $\mathrm{O}_{2}$ and potentially higher materials degradation caused by the presence of excess oxygen at high temperatures and the corrosive potential of any possible fuel sulphur content.

In order to show oxyfuel combustion with carbon capture and storage is feasible, seventeen largescale projects were initiated worldwide [4]. In most of these projects coal/biomass were the primary fuels. An important example is provided by the Callide Oxyfuel (coal) Project in Australia [5] which consists of the retrofit of a unit of $30 \mathrm{MW}$ into an oxyfuel boiler for electricity generation with $\mathrm{CO}_{2}$ purification, capture and storage. When the project finished in March 2015, the oxy-combustion unit had operated for 10,000 $\mathrm{h}$ and the Compression and Purification Unit (CPU) for 5,500 h [6]. Four of the seventeen projects were recently cancelled or are currently moth-balled due to lack of funding or profitability. The Compostilla Phase II project located in Spain is one of these, which when it was operating showed an impressive net efficiency of $33 \%$ capturing $91 \%$ of the produced $\mathrm{CO}_{2}$ [7].

There is a growing worldwide attempt to convert coal-fired power plants to gas-fired plants due to their lower emissions. Consequently, by increasing the number of natural gas power plants, $\mathrm{CO}_{2}$ capture from gas-fired power plants (Gas-CCS) is presently receiving more attention (e.g., Gas-FACTS a CCS Research Council funded project in the UK). One of the alternatives in Gas-CCS is the oxycombustion gas turbine cycles and, therefore, further investigations on these cycles look more promising than before.

This technical evaluation addresses a specific type of oxyfuel cycles known as oxy-turbine which are characterised by combusting natural gas or syngas with high-purity oxygen previously separated using a cryogenic air separation unit (ASU), ion transfer membrane (ITM) or other technology. Political, Environmental, Social, Technological, Legislative and Economic (PESTLE) risk analysis and a multi-criteria decision analysis carried out using DECERNS (Decision Evaluation in Complex Risk Network Systems) software have been employed to evaluate and compare different cycles.

This paper assesses nineteen different oxy-turbine power cycles which are shown with their specifications in Table 1. 
Table 1: Specification review of the nineteen studied oxy-turbine power cycles

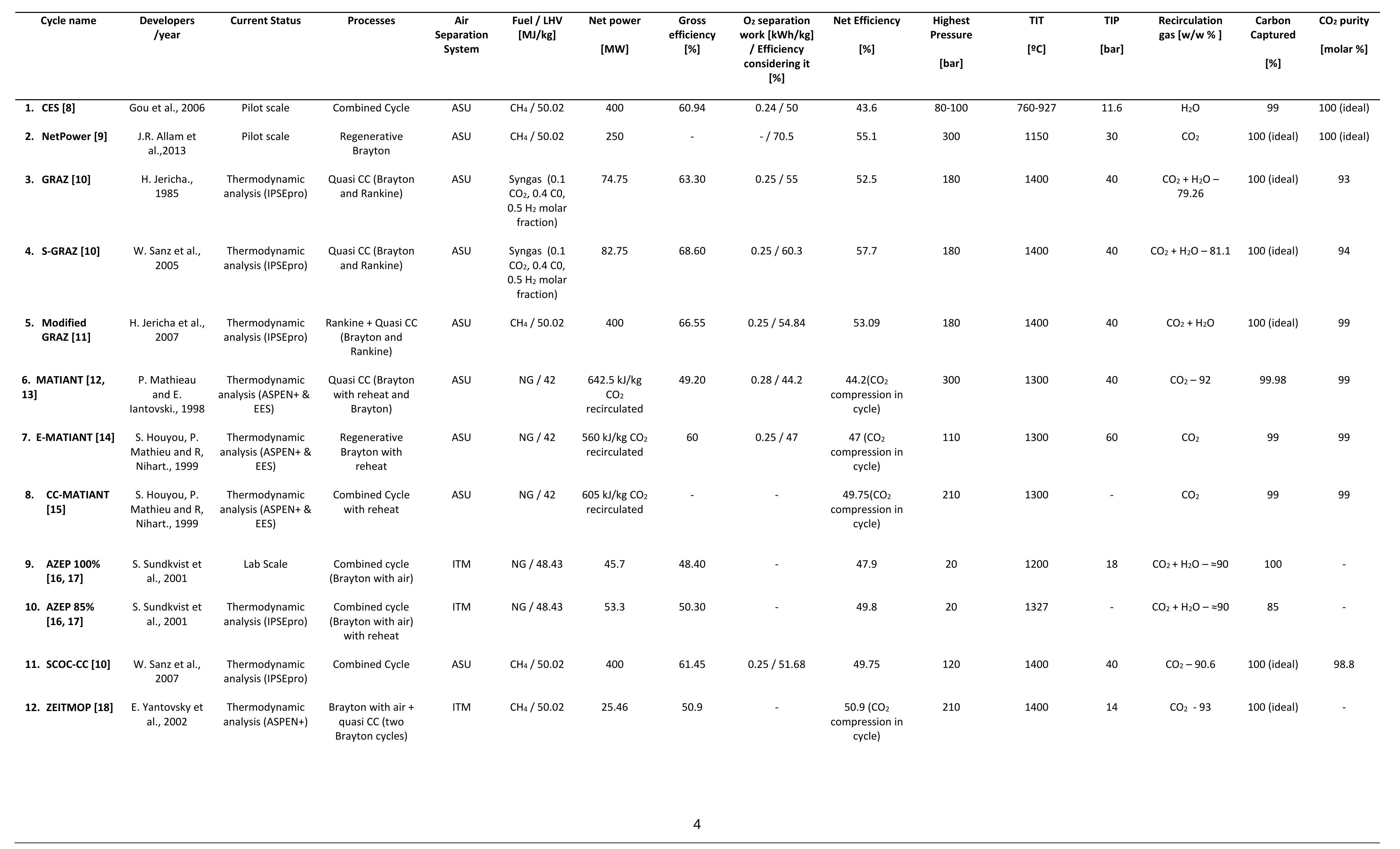




\begin{tabular}{|c|c|c|c|c|c|c|c|c|c|c|c|c|c|c|c|}
\hline Cycle name & $\begin{array}{l}\text { Developers } \\
\text { /year }\end{array}$ & Current Status & Processes & $\begin{array}{c}\text { Air } \\
\text { Separation } \\
\text { System }\end{array}$ & $\begin{array}{c}\text { Fuel / LHV } \\
{[\mathrm{MJ} / \mathrm{kg}]}\end{array}$ & $\begin{array}{c}\text { Net power } \\
\text { [MW] }\end{array}$ & $\begin{array}{c}\text { Gross } \\
\text { efficiency } \\
{[\%]}\end{array}$ & $\begin{array}{c}\mathrm{O}_{2} \text { separation } \\
\text { work [kWh/kg] } \\
/ \text { Efficiency } \\
\text { considering it } \\
\text { [\%] }\end{array}$ & $\begin{array}{c}\text { Net Efficiency } \\
\text { [\%] }\end{array}$ & $\begin{array}{c}\text { Highest } \\
\text { Pressure } \\
\text { [bar] }\end{array}$ & $\begin{array}{l}\text { TIT } \\
\text { [oC] }\end{array}$ & $\begin{array}{c}\text { TIP } \\
\text { [bar] }\end{array}$ & $\begin{array}{l}\text { Recirculation } \\
\text { gas [w/w \% ] }\end{array}$ & $\begin{array}{c}\text { Carbon } \\
\text { Captured } \\
{[\%]}\end{array}$ & $\begin{array}{l}\mathrm{CO}_{2} \text { purity } \\
\text { [molar \%] }\end{array}$ \\
\hline $\begin{array}{l}\text { 13. OXYF-REF } \\
{[19,20]}\end{array}$ & $\begin{array}{l}\text { N. Zhang and N. } \\
\text { Lior, } 2008\end{array}$ & $\begin{array}{l}\text { Thermodynamic } \\
\text { analysis (ASPEN+) }\end{array}$ & $\begin{array}{l}\text { Quasi CC (Brayton } \\
\text { and Rankine) }\end{array}$ & ASU & NG / 46.3 & 404.84 & 64.33 & $-/ 55.42$ & 50.82 & 150 & 1300 & 15 & $\mathrm{CO}_{2}+\mathrm{H}_{2} \mathrm{O}-74.1$ & 100 (ideal) & 84 \\
\hline $\begin{array}{l}\text { 14. COOLCEP-S } \\
\text { [21] }\end{array}$ & $\begin{array}{l}\text { S Deng et al., } \\
2002\end{array}$ & $\begin{array}{l}\text { Thermodynamic } \\
\text { analysis (ASPEN+) }\end{array}$ & $\begin{array}{l}\text { Regenerative } \\
\text { Rankine-like }\end{array}$ & ASU & LNG / 49.2 & 20 & 59.1 & $0.22 / 52.29$ & $\begin{array}{l}52.29 \text { (no CO } \\
\text { compression } \\
\text { considered) }\end{array}$ & 73.5 & 900 & 28 & $\mathrm{CO}_{2}-97$ & 100 & 100 (ideal) \\
\hline $\begin{array}{l}\text { 15. Water-steam } \\
\text { Rankine cycle } \\
\text { with a steam- } \mathrm{CO}_{2} \\
\text { recuperative- } \\
\text { reheat cycle [22] }\end{array}$ & $\begin{array}{c}\text { C. Gou, R. Cai, } \\
\text { and H. Hong., } \\
2006\end{array}$ & $\begin{array}{l}\text { Thermodynamic } \\
\text { analysis (ASPEN+) }\end{array}$ & $\begin{array}{l}\text { Quasi CC (Brayton } \\
\text { with reheat and } \\
\text { Rankine) }\end{array}$ & ASU & $\mathrm{CH}_{4} / 50.02$ & 67.63 & - & $0.25 /-$ & 47.12 & 300 & 1300 & 38.8 & $\mathrm{H}_{2} \mathrm{O}$ & $>99$ & $>99$ \\
\hline $\begin{array}{l}\text { 16. Water-steam } \\
\text { Rankine cycle } \\
\text { with steam- } \mathrm{CO}_{2} \\
\text { recuperative- } \\
\text { reheat cycle and } \\
\text { a topping } \\
\text { Brayton cycle } \\
\text { [22] }\end{array}$ & $\begin{array}{c}\text { C. Gou, R. Cai, } \\
\text { and H. Hong., } \\
2006\end{array}$ & $\begin{array}{l}\text { Thermodynamic } \\
\text { analysis (ASPEN+) }\end{array}$ & $\begin{array}{l}\text { Quasi CC (Brayton } \\
\text { with reheat and } \\
\text { Rankine) }\end{array}$ & ASU & $\mathrm{CH}_{4} / 50$ & 72.56 & - & $0.25 /-$ & 50.64 & 300 & 1300 & 38.8 & $\begin{array}{c}\mathrm{H}_{2} \mathrm{O}(\mathrm{COMB} 1) \\
\text { and } \mathrm{CO}_{2}+\mathrm{H}_{2} \mathrm{O} \\
(\mathrm{COMB2})\end{array}$ & $>99$ & $>99$ \\
\hline $\begin{array}{l}\text { 17. Novel } \mathrm{O}_{2} / \mathrm{CO}_{2} \\
\text { [23] }\end{array}$ & $\begin{array}{l}\text { W. Cao and D. } \\
\text { Zheng., } 2006\end{array}$ & $\begin{array}{l}\text { Thermodynamic } \\
\text { analysis (ASPEN+) }\end{array}$ & $\begin{array}{l}\text { Regenerative } \\
\text { Brayton }\end{array}$ & ASU & $\mathrm{CH}_{4} / 50.02$ & 24.8 & 59.5 & $0.28 / 51.1$ & 48.9 & 10 & 1300 & 8.85 & $\mathrm{CO}_{2} .95 .6$ & 100 (ideal) & 99.5 \\
\hline $\begin{array}{l}\text { 18. LNG quasi- } \\
\text { combined } \\
\text { supercritical } \mathrm{CO}_{2} \\
\text { Rankine cycle } \\
\text { [24] }\end{array}$ & $\begin{array}{l}\text { N. Zhang and N. } \\
\text { Lior., } 2003\end{array}$ & $\begin{array}{c}\text { Thermodynamic } \\
\text { analysis }\end{array}$ & $\begin{array}{l}\text { Quasi CC (Brayton } \\
\text { and Rankine-like) }\end{array}$ & ASU & $\begin{array}{c}\mathrm{CH}_{4} / 50.02 \\
\text { (Assumed } \\
\text { that } \mathrm{LNG} \text { is } \\
\mathrm{CH}_{4} \text { ) }\end{array}$ & 71.4 & 72.3 & $0.25 / 65.1$ & 65 & 156 & 1300 & 29.1 & $\mathrm{CO}_{2}-94.3$ & 100 (ideal) & 100 (ideal) \\
\hline $\begin{array}{l}\text { 19. ZE-SOLRGT } \\
\text { [25] }\end{array}$ & $\begin{array}{l}\text { Zhang and Lior., } \\
2012\end{array}$ & $\begin{array}{l}\text { Thermodynamic } \\
\text { analysis (ASPEN+) }\end{array}$ & $\begin{array}{l}\text { Quasi CC (Brayton } \\
\text { and Rankine) }\end{array}$ & ASU & $\mathrm{CH}_{4} / 50.03$ & 496.07 & 61.54 & $0.25 / 54.27$ & 50.7 & 157.5 & 1308 & 14.55 & $\mathrm{CO}_{2}+\mathrm{H}_{2} \mathrm{O}-59$ & 100 (ideal) & 87 \\
\hline
\end{tabular}


According to Table 1, the key factors which determine the availability and performance of the oxyturbine panorama are the current status and the net efficiency. Considering the current status, most of the cycles can be considered as being under development (e.g., at the stage of being investigated via thermodynamic analysis). In fact only AZEP, CES and NetPower can be considered to be at an advanced status given that CES and NetPower cycles have been built at the pilot scale to demonstrate their feasibility $[8,26]$ followed by the AZEP whose components have been tested at laboratory scale [27]. Overall, the net efficiency of the different cycles ranges between 43.6 and $65 \%$, comparable to a combined cycle gas turbine (CCGT) power plant [28].

The core of CES's design is adapted from rocket engine technology and burns gaseous or liquid fuels with pure gaseous oxygen. The high-pressure oxy-combustor produces a steam/ $\mathrm{CO}_{2}$ working fluid for expansion in a turbine. NetPower, however, uses supercritical $\mathrm{CO}_{2}$ as the working fluid in a radically new cycle. Carbon capture in oxy power cycles is an inherent feature of the process, not an add-on with very large parasitic loads, as with "conventional" CCS approaches. For most of these cycles compatible fuels include natural gas, syngas from coal, refinery residues, biogases, landfill gas, and oil/water emulsions. A demonstration project for the CES cycle including the design, analysis, and testing of a modified Siemens SGT-900 gas turbine was done by Clean Energy Systems (CES), with support from Siemens Energy and Florida Turbine Technologies (FTT), through a U.S. Department of Energy (DOE) funding program [29]. Component test results proved the feasibility of the gas turbine conversion to an oxy-fuel turbine; however, further testing was recommended to verify performance at higher power levels, and longer durations [30]. For demonstration of the NETPower cycle, the company is partnering with CB\&I, Toshiba Corporation, and Exelon Corporation to demonstrate this new system in a $50 \mathrm{MWt}$ natural gas power plant [31].

\subsection{Classification by recirculation}

Regarding the recirculation of flue gases, researchers have carried out several studies in order to determine if recirculating $\mathrm{CO}_{2}$, steam, or a mixture of both offers more thermodynamic advantages. Thus, these cycles were classified using these criteria, as shown in Table 2.

Table 2: Classification of oxy-turbine cycles by recirculation fluid

\begin{tabular}{ccc}
\hline \multicolumn{3}{c}{ Recirculated working fluid } \\
\hline $\mathrm{CO}_{2}$ & $\mathrm{H}_{2} \mathrm{O}$ & $\mathrm{CO}_{2}+\mathrm{H}_{2} \mathrm{O}$ \\
\hline NetPower & $\mathrm{CES}$ & Graz cycles* \\
MATIANT* & Water cycles* & AZEP* \\
SCOC-CC & & OXYF-REF \\
ZEITMOP & ZE-SOLRGT \\
COOLCEP-S & \\
Novel $\mathrm{O}_{2} / \mathrm{CO}_{2}$ & \\
LNG quasi-combined & \\
* refers to all their variants
\end{tabular}

$\mathrm{CO}_{2}$ is the most popular recirculation fluid for the oxy-turbine cycles reviewed. In the condenser, $\mathrm{CO}_{2}$ and steam are separated by steam condensation and the remaining carbon dioxide is divided into two streams. Usually, at least $90 \%$ of the $\mathrm{CO}_{2}$ produced is recirculated to the combustor, whereas the remaining part is purified and compressed for further applications [32, 33]. For example, in Semi- 
Closed Oxy-fuel Combustion Combined Cycle (SCOC-CC), recirculated $\mathrm{CO}_{2}$ is represented as a red line in the diagram shown in Figure 1.

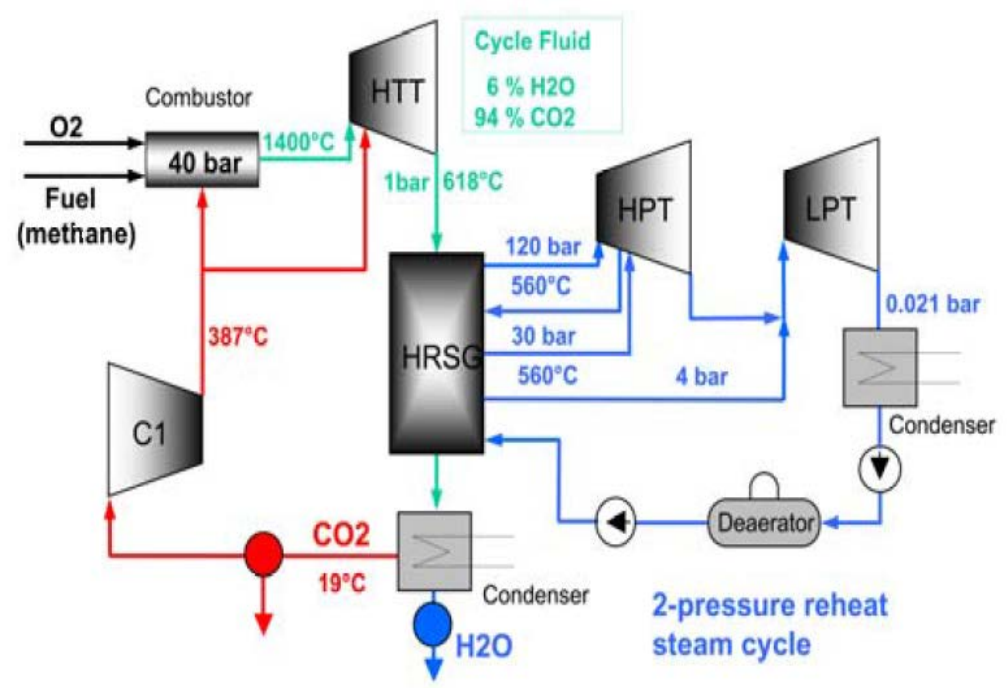

Legend: C1 - Compressor, HTT - High-temperature turbine, HRSG - Heat recovery steam generator, HPT - High-pressure turbine, LPT Low-pressure turbine

Figure 1: SCOC-CC schematic [10]

Another option, only seen in two of the considered oxy-turbine cycles, is to use some of the steam separated in the condenser instead of $\mathrm{CO}_{2}$. The $\mathrm{CES}$ cycle illustrates the recirculation process with water, which is represented in Figure 2 as a dark blue line.

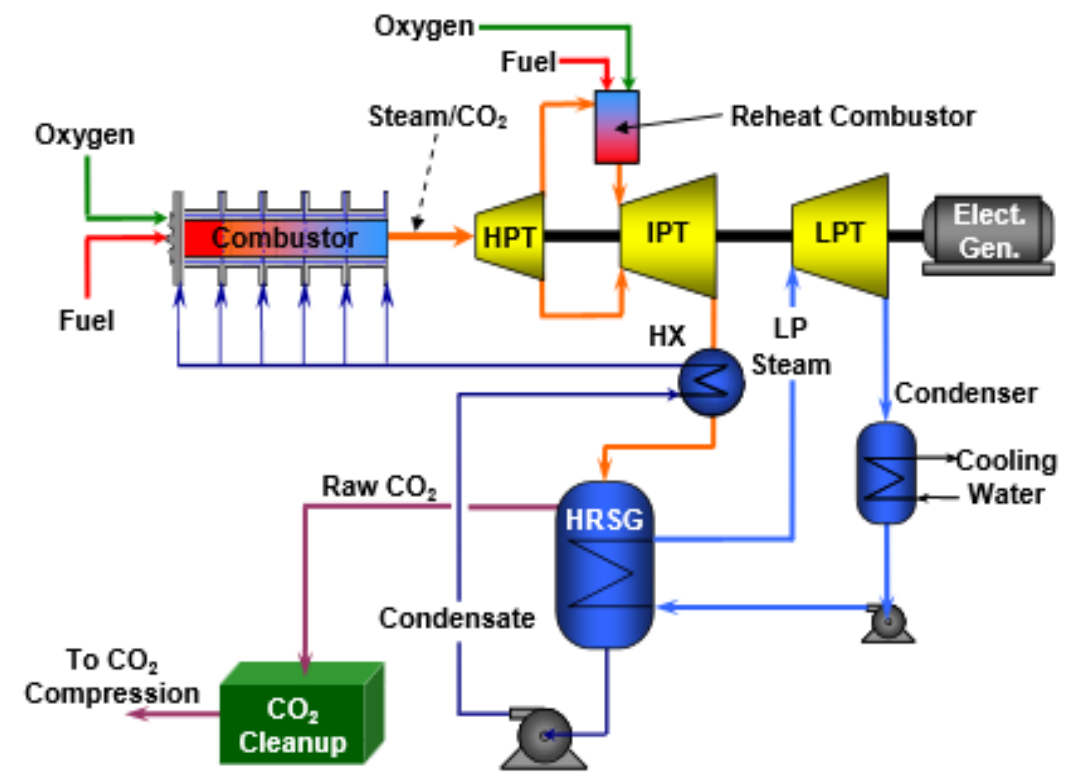

Legend: HX - Heat Exchanger, HTT - High-temperature turbine, HRSG - Heat recovery steam generator, HPT - High-pressure turbine, IPT Intermediate-pressure turbine, LPT - Low-pressure turbine

Figure 2: CES cycle schematic [8] 
The last group includes those cycles which recirculate a mixture of $\mathrm{CO}_{2}$ and $\mathrm{H}_{2} \mathrm{O}$. The $\mathrm{S}$-Graz cycle uses this process as it is represented in Figure 3.

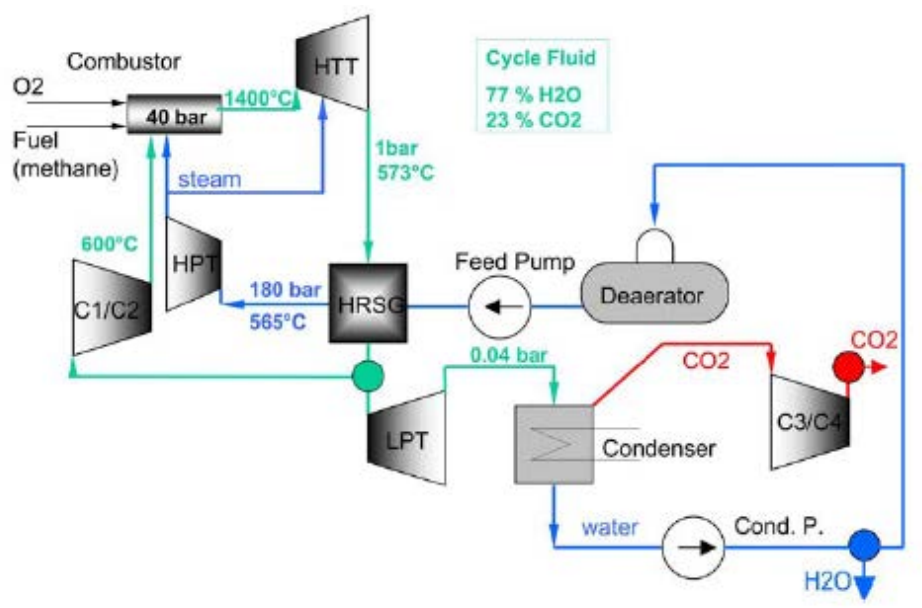

Legend: C1/C2 \& C3/C4 - Compressor, HTT - High-temperature turbine, HRSG - Heat recovery steam generator, HPT - High-pressure turbine, LPT - Low-pressure turbine

Figure 3: S-Graz cycle schematic [11]

Depending on the recirculation of working fluid in gas turbines $\left(\mathrm{CO}_{2}, \mathrm{H}_{2} \mathrm{O}\right.$ and $\left.\mathrm{CO}_{2}+\mathrm{H}_{2} \mathrm{O}\right)$, oxy-fuel technologies benefit or suffer depending on their cycles. First of all, recycling $\mathrm{CO}_{2}$ minimises the CCS costs by the use of almost $96 \%$ of the total $\mathrm{CO}_{2}$; however, the turbomachinery must be completely redesigned (gas turbine, combustor, compressor and heat exchanger) since higher temperatures and pressures are achieved [34]. In addition, the materials suffer from some limitations such as corrosion and incomplete combustion due to high levels of $\mathrm{CO}, \mathrm{H}_{2}$ and $\mathrm{OH}^{-}$[35]. In the second case, $\mathrm{H}_{2} \mathrm{O}$ (steam) lowers capital costs whilst increasing the net efficiencies, since steam turbines are proven technologies; on the other hand, an extra heat recovery system and more working compressors need to be installed at considerably high pressures and temperatures $\left(1300^{\circ} \mathrm{C}\right.$ and $30-50 \mathrm{MPa}$ ) [3]. Last but not least, $\mathrm{CO}_{2}+\mathrm{H}_{2} \mathrm{O}$ offer a balanced approach meeting the constraints of CCS costs and energy efficiency as well as a drop in air separation costs [36]. By contrast as retrofitting, they might present lower efficiencies and low power outputs [37].

\subsection{Classification by power generation}

In order to classify the oxy-turbine power cycles from a thermodynamic point of view, the authors have suggested five different concepts relevant to power generation. Concretely, these processes modify the thermodynamic parameters of the working fluid, changing mainly its pressure and temperature to increase the efficiency of the cycle. Table 3 shows this classification: 
Table 3: Classification of oxy-turbine cycles by their power generation processes

\begin{tabular}{|c|c|c|c|c|}
\hline $\begin{array}{c}\text { Regenerative } \\
\text { Brayton }\end{array}$ & $\begin{array}{c}\text { Regenerative } \\
\text { Brayton with } \\
\text { reheat }\end{array}$ & $\begin{array}{l}\text { Regenerative } \\
\text { Rankine-like }\end{array}$ & $\begin{array}{l}\text { Combined } \\
\text { cycle }\end{array}$ & $\begin{array}{l}\text { Quasi-combined } \\
\text { cycle }\end{array}$ \\
\hline NetPower & E-MATIANT & COOLCEP-S & CC-MATIANT & MATIANT \\
\hline \multirow[t]{6}{*}{ Novel $\mathrm{O}_{2} / \mathrm{CO}_{2}$} & & & SCOC-CC & Graz Cycles* \\
\hline & & & AZEP* & ZE-SOLRGT \\
\hline & & & CES & Water Cycles* \\
\hline & & & & OXYF-REF \\
\hline & & & & LNG quasi-combined \\
\hline & & & & ZEITMOP \\
\hline
\end{tabular}

* refers to all their variants

The five different groups are described as follows:

Regenerative Brayton: After the expansion of the working fluid in a gas turbine, the calorific energy of the flue gases is used to heat other parts of the working fluid. In this type of cycle, the working fluid does not suffer any phase change. One example of this is the Novel $\mathrm{O}_{2} / \mathrm{CO}_{2}$ cycle shown in Figure 4, where the flue gases at point 8 go to a heat exchanger in order to preheat the recirculated fluid before entering the combustor.

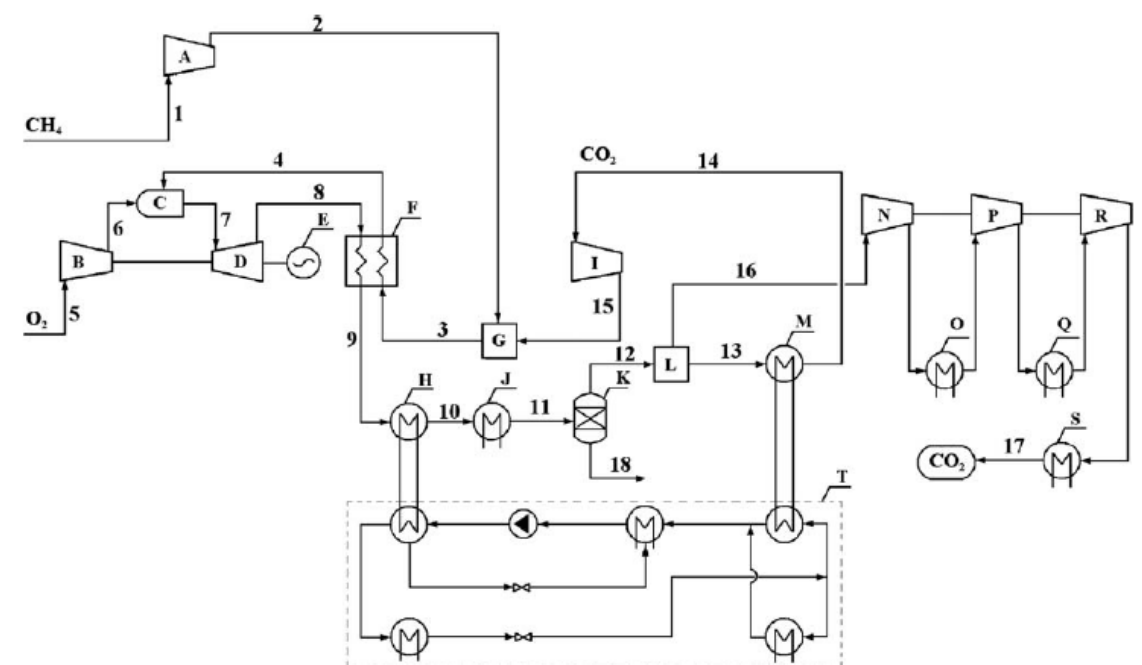

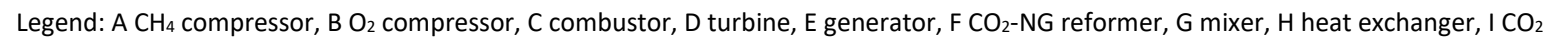
compressor, J cooler, O\&Q intercooler, $\mathrm{K}$ separator, L splitter, $\mathrm{M} \mathrm{CO}_{2}$ inlet cooler, N,P, R compressor, $\mathrm{S}$ condenser , T ammonia absorption refrigeration

Figure 4: Novel $\mathrm{O}_{2} / \mathrm{CO}_{2}$ cycle schematic [23]

Regenerative Brayton with reheat: The cycles included in this group have a similar working principle to the first group but contain a reheat stage. In this stage and after the first expansion, the working fluid goes into another combustor and the flue gases are further expanded. The E-MATIANT, shown in Figure 5 , is the only oxy-turbine cycle that belongs to this group. 


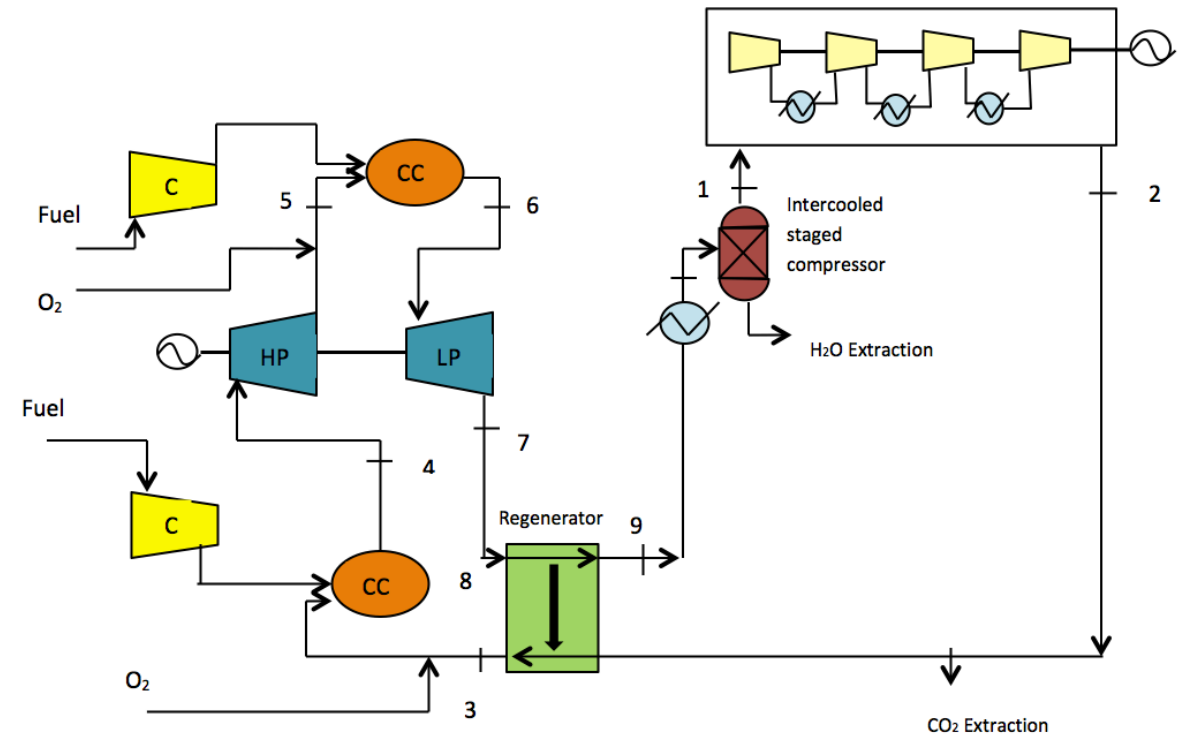

Legend: C-Compressor, CC - Combustion chamber, HP - High-pressure turbine, LP - Low-pressure turbine

Figure 5: E-MATIANT cycle schematic [38]

Regenerative Rankine-like: This is similar to the Regenerative Brayton but in this case the working fluid suffers phase changes (gas-liquid-gas). In Figure 6, the COOLCEP-S cycle is shown. The $\mathrm{CO}_{2}$ is liquefied in the condenser (point 13) and evaporated in EVA1 (point 3).

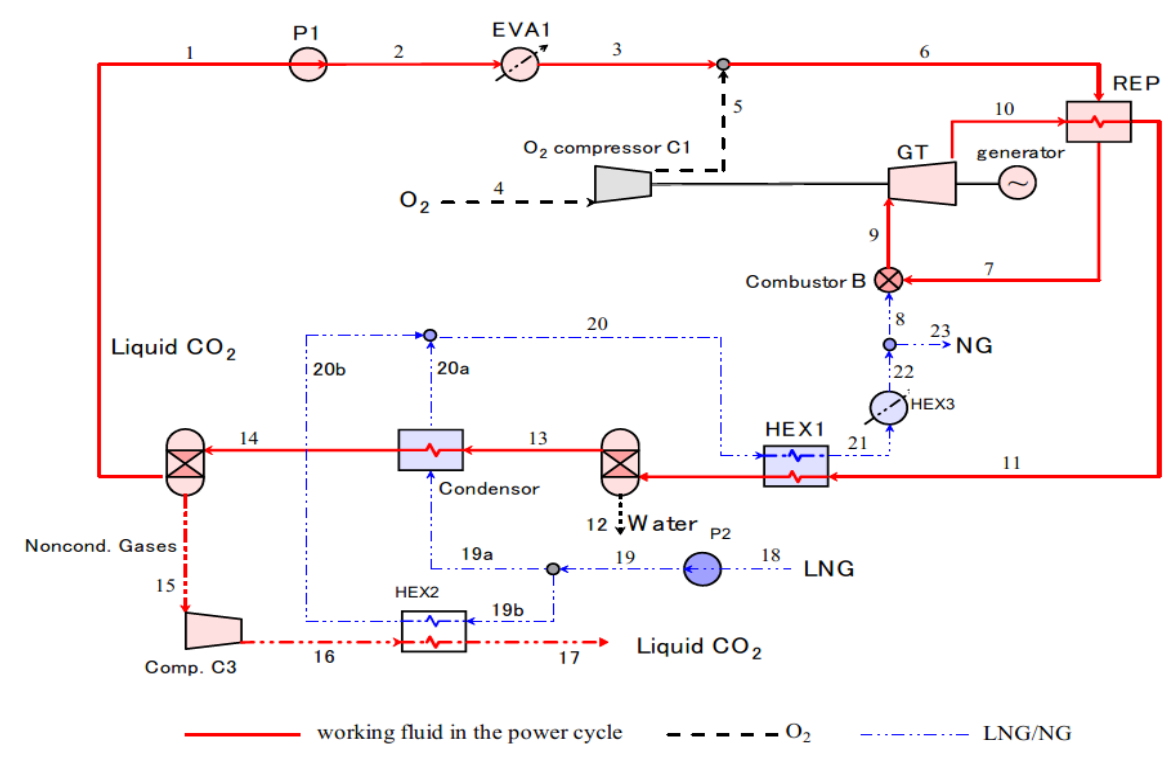

Legend: P1 \& P2 - Pump; HEX1 HEX2, HEX3 - Heat Exchanger; EVA1 - Evaporator; REP - Regenerator; GT - Gas turbine; NG - Natural gas; LNG - Liquefied natural gas

Figure 6: COOLCEP-S Cycle schematic [21]

Combined Cycle: It combines two different cycles, Brayton and Rankine. The flue gases from the Brayton cycle are used to generate steam in the Rankine cycle through separated circuits. The AZEP cycle follows this principle, as seen in Figure 7. 


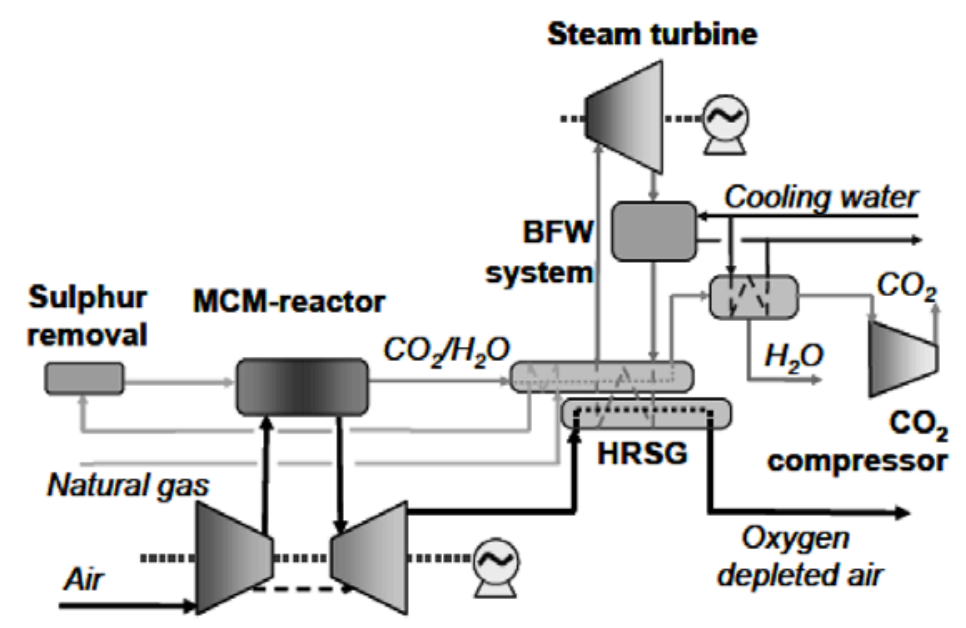

Legend: BFW - Boiled feed water, MCM - Oxygen mixed conducting membrane, HRSG - Heat recovery steam generator

Figure 7: AZEP cycle schematic [17]

Quasi-Combined Cycle: This combines two different cycles, one high-temperature and the other lowtemperature (not necessarily a Brayton linked to a Rankine), where the working fluids are in a common circuit. The Graz cycle belongs to this group, and is shown in Figure 8. The flue gases coming from the high-temperature turbine (HTT) are used as a hot sink to generate steam in the heat recovery steam generator (HRSG). After this, the water is separated by condensation and is delivered to the previously mentioned HRSG where it becomes steam.

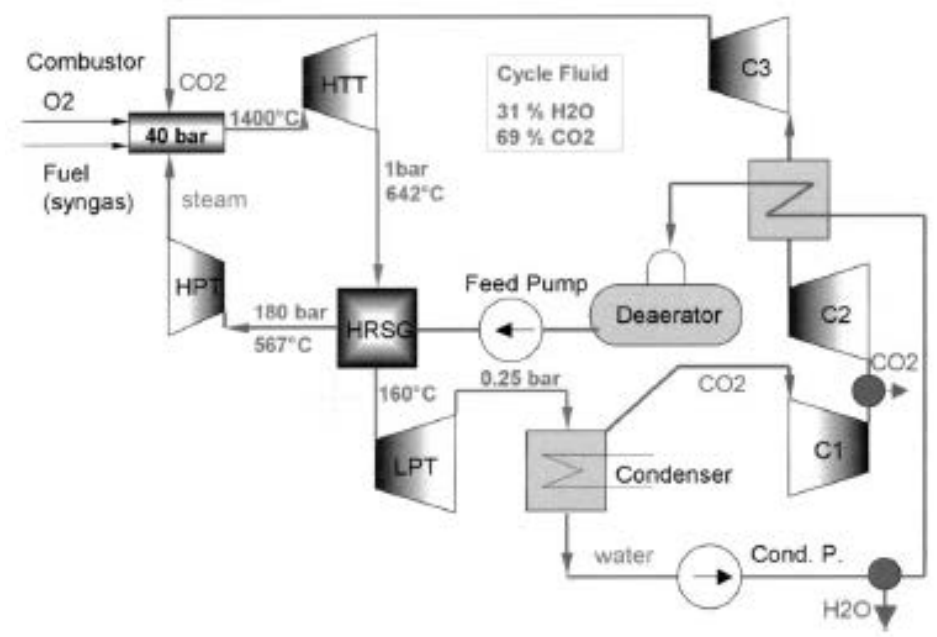

Legend: C1, C2 \& C3 - Compressor, HTT - High-temperature turbine, HRSG - Heat recovery steam generator, HPT - High-pressure turbine, LPT - Low-pressure turbine

Figure 8: Graz cycle schematic [10]

\subsection{Cycle integration with renewables}

To implement renewable energy approaches in the oxy-turbine power plant there are only three technologically and economically viable sources: solar (thermal), biomass and biofuels (liquid and gas phases). The lack of research in this field has made it impossible at present to explore other sustainable sources such as wind or geothermal in oxy-turbine power plants. 


\subsubsection{Solar}

There are several oxy-turbine technologies that back their power generation with solar thermal to heat water and optimise the HRSG system. The main technology is ZE-SOLGRT, which is an adaptation of the Graz cycle implementing solar thermal [25]. There are also three new systems that incorporate solar thermal: the Solar Thermal Hybrid $\mathrm{H}_{2} \mathrm{O}$ turbine power generation System (STHS), the Advanced oxy-fuel Hybrid Power Generation cycle (AHPS) [39] and the Hybrid and Improved CES cycle (HICES) [22].

These technologies offer the possibility of heating the working fluid and optimising the HRSG, minimising fuel and oxygen consumption. However, in general, they produce low cycle efficiency compared to the standard oxy-turbine cycles. In addition, they are highly affected by the intermittency of solar radiation due to seasonality and geographical limitations.

\subsubsection{Biomass}

Currently, biomass is used as fuel in oxyfuel technologies by using it with different types of coal (anthracite, bituminous, peat and lignite) in a boiler to generate steam. However, the use of solid fuels in oxy-turbine cycles would damage the turbine when flue gases are expanded. The possibility of implementing solid fuels (coal) in an oxy-turbine cycle was studied by Oki et al. [40]. They concluded that it would be feasible only by integrating a gasifier into a combined cycle (IGCC). On the other hand, several thermogravimetric analyses have been conducted to study the feasibility of employing biomass in oxy-turbine cycles. These studies suggest the possibility of using several biological feedstocks such as forest residues (e.g., from poplar and switchgrass), agricultural residues (e.g., corn stover, sugarcane bagasse, pine sawdust, torrefied pine sawdust and olive pits) and waste (e.g., MSW, sewage sludge and slurry) [41, 42].

\subsubsection{Biofuels (liquid and gaseous states)}

There are studies on the use of biofuels such as diesel, ethanol and glycerol (previously treated) in oxy-turbine power plants [43-45]. Indeed, CES offers assurances that its technology is ready to be fuelled from landfill gas, bio-digester gas and glycerine (glycerol) followed by oxyfuel combustion. Additionally, oxyfuel technologies can help third and fourth generation biofuels since both microalgae and bioengineered microbes are fed with sequestered $\mathrm{CO}_{2}$ to grow and produce biofuels such as ethanol, diesel, jet fuel and gasoline [46].

\section{Research methodology}

The evaluation of each oxy-turbine cycle is based on a PESTLE risk analysis which stands for assessments of the cycles from Political, Environmental, Social, Technological, Legislative and Economic (PESTLE) points of view [47]. The complexity of evaluating the political, legislative and social factors for each cycle has led to a general analysis of these three aspects applied to the CCS field without going into detail for each specific cycle.

A Multi-Criteria Decision Analysis (MCDA) has been carried out to evaluate the technological, economic, environmental and social factors using DECERNS software [48]. This type of analysis evaluates different alternatives attending to different factors, which have a certain weight assigned in order to decide which alternative is the most appropriate. Due to better availability of the technical information in the literature, AZEP, CES, E-MATIANT, Modified Graz, NetPower and SCOC- 
CC have been chosen for this analysis. The results of this study enable the identification of the best cycle for the considered factors. Our contribution is to conduct a MCDA according to the data found in the literature, thus, a robust comparison between the most developed oxy-fuel cycles and a base case (CCGT) can be done.

\subsection{Political and Legislative}

In general, CCS is a developing technology that has not yet been proven at large scale. It has been estimated that commercial power plants with CCS technology will not be deployed until the second tranche of units is built [49]. The first tranche will, therefore, be useful to identify the technical problems that can arise in real power plants with these technologies. Consequently, several political measures should be applied with the intention of enhancing the economic viability of this type of power plant.

The main driver that will make CCS technology profitable for investors will be some form of $\mathrm{CO}_{2}$ tax. This tax will not be high enough to replace conventional fossil fuel power plants until the low-carbon technologies are as commercialised as the conventional ones and sufficiently developed to cover most of the energy demand. Therefore, until that happens, other measures are needed to promote the development and proliferation of CCS technologies. Such measures should serve as a support for building new plants with carbon capture or for retrofitting existing power plants with this technology to start capturing carbon dioxide. The measures could include either direct financing or imposing measures that restrict the amount of emissions by a plant or by a sector.

An example of an adopted measure is the one implemented first in California and later in some other states in the USA and in Europe [49]. The Electricity Emissions Performance Standards (EPSs) limits the amount of $\mathrm{CO}_{2} / \mathrm{MWh}$ that a power plant can emit. For example, in the EU the limit imposed is $350 \mathrm{~kg} \mathrm{CO} / \mathrm{MWh}$ applicable for new and existing plants in 2020 and 2025, respectively [50]. An important consideration is that when a CCS technology is applied in a new plant, it is built to capture high degree of $\mathrm{CO}_{2}$ (at least $85 \%$ ). Otherwise, the limit of $350 \mathrm{~kg} \mathrm{CO}_{2} / \mathrm{MWh}$ on the emissions amount could be equally achieved by a highly efficient power plant with no carbon capture or by retrofitting a small part of the plant leaving the rest without carbon capture. Consequently, this will help the mitigation of climate change and demonstration of these technologies at small scale, but not properly promote the construction and development of CCS technologies because it does not provide any financial support, but only imposes a legislative restriction.

Another example in terms of measures is the EU Emission Trading Scheme. In 2009 the EU set 300 million emission allowances to support CCS and innovative renewable energy projects [49]. An EU allowance permits the holder to emit 1 tonne of $\mathrm{CO}_{2}$. This incentive is similar to the Renewable Obligation Certificates (ROCS) in the UK, but unlike them, the sectoral standard market seems less likely to collapse until the CCS projects are consolidated. Overall, it appears that the EU Emission Trading Scheme provides a greater incentive than the EPS to build new CCS plants, since the less they emit the more financial support they obtain. Overall, it seems to be the most effective technique since it not only penalises $\mathrm{CO}_{2}$ emissions but also finances deployment of $\mathrm{CCS}$ technologies. 


\subsection{Technological}

To evaluate the selected cycles in terms of technological aspects, two characteristics have been considered: the net efficiency and the technical level of readiness, with $60 \%$ and $40 \%$ weight, respectively, since one of the aims of oxy-turbine cycles is to achieve efficiencies comparable to those obtained in conventional plants. A higher weight percentage is given to the net efficiency (60\%) compared to the technical level of readiness (40\%) because oxy-fuel technologies are looking forward to meet the net efficiency of CCGTs. Furthermore, the stage of development in most of the oxy-turbine cycles is still in the thermodynamic assessment phase and, therefore, it is important to bring the readiness level to attention if we are seeking an available practical replacement option to CCGT cycles.

The net efficiency and the level of readiness of each cycle appear in Table 4.

The level of readiness was assigned according to the stage of development of each cycle, graded from 1 to 9 following the "Technology Readiness Assessment (TRA) Guidance" for the energy supply sector [51]. Each level refers to a specific stage of development according to the literature review and reports of the oxy-fuel technologies, as shown in Table 4.

\subsection{Economic}

The two factors used for the economic evaluation are the cost of electricity (COE) which describes how much it costs to generate $1 \mathrm{kWh}$ of electricity taking into account all the expenses to produce this amount of energy (e.g., fuel cost, operation, etc.) and the capital costs (CAPEX). Although the COE seems to be more significant in terms of power plant benefits, a low CAPEX will attract stakeholders to invest in it. For this reason, the same weight (50\%) has been assigned to both factors.

Table 4: Net efficiency and level of readiness of each selected cycle

\begin{tabular}{lccccccc}
\hline & $\begin{array}{c}\text { AZEP } \\
\mathbf{1 0 0 \%} \\
{[\mathbf{1 6 , 1 7 ]}}\end{array}$ & $\begin{array}{c}\text { CCGT } \\
{[\mathbf{2 8}]}\end{array}$ & $\begin{array}{c}\text { CES } \\
{[\mathbf{8}]}\end{array}$ & $\begin{array}{c}\text { E-MATIANT } \\
{[\mathbf{1 4}]}\end{array}$ & $\begin{array}{c}\text { Modified } \\
\text { Graz [10] }\end{array}$ & $\begin{array}{c}\text { NetPower } \\
{[\mathbf{5 0}]}\end{array}$ & $\begin{array}{c}\text { SCOC-CC } \\
{[11]}\end{array}$ \\
\hline $\begin{array}{l}\text { Net } \\
\text { Efficiency (\%) }\end{array}$ & 47.9 & 58 & 43.6 & 47 & 53.1 & $55.1^{*}$ & $49.8^{* *}$ \\
Readiness & 4 & 9 & 7 & 5 & 5 & 6 & 5 \\
\hline
\end{tabular}

*this value is attributed by independent researchers [52] which lies between the one provided by the company [9] and Llorente [38], 58.9 and 51.9\%, respectively.

$* *$ this value approximates efficiencies presented in other studies $[53,54]$

The economic data provided for each cycle have different assumptions depending on factors such as the power plant size, the fuel price, the discount rate, etc. Thus, in order to show the results and make them comparable, the costs for each cycle have been divided by the costs for its reference plant (CCGT), obtaining a ratio that represents their overcost. For instance, taking into account a COE of $39.5 € / \mathrm{MWh}$ for the CCGT and $53.32 € / \mathrm{MWh}$ for the AZEP $100 \%$ the COE overcost ratio is 1.35 . The overcost ratio of each cycle is shown in Table 5. 
However, it is important to take into account that these costs include the implementation and financing of these cycles as a project but R\&D investment is not included, which would increase the cost considerably. This investment will depend on the complexity and novelty of the cycle and components on them but these costs cannot be estimated by the authors of this study.

Table 5: CAPEX and COE overcost ratio of each selected cycle

\begin{tabular}{cccccccc}
\hline & $\begin{array}{c}\text { AZEP } \\
100 \%\end{array}$ & CCGT & $\begin{array}{c}\text { CES } \\
{[55]}\end{array}$ & $\begin{array}{c}\text { E-MATIANT } \\
{[56]}\end{array}$ & $\begin{array}{c}\text { Modified } \\
\text { Graz [10] }\end{array}$ & NetPower & $\begin{array}{c}\text { SCOC-CC } \\
{[10]}\end{array}$ \\
\hline $\begin{array}{c}\text { CAPEX } \\
\text { overcost }\end{array}$ & 1.23 & 1 & 1.36 & 1.1 & 1.69 & 1.27 & 1.64 \\
$\begin{array}{c}\text { COE } \\
\text { overcost }\end{array}$ & 1.35 & 1 & 1.1 & 1.1 & 1.2 & 1.04 & 1.26 \\
\hline
\end{tabular}

\subsection{Environmental}

The environmental aspect of the different cycles has been evaluated based on the Life Cycle Assessment (LCA). This technique assesses the environmental impacts associated with all stages of a product's life from cradle to grave. Hence, it evaluates the equivalent $\mathrm{CO}_{2}$ emissions per $\mathrm{kWh}$ that each cycle releases during the 25 years of its life cycle including the construction of the plant, the emissions emitted during its use considering possible losses in compressors and during transport, the maintenance and repair operations and the demolition of the plant. Table 6 shows these emissions.

Table 6: $\mathrm{CO}_{2}$ emissions for each selected cycle

\begin{tabular}{cccccccc}
\hline AZEP & CCGT & CES & $\begin{array}{c}\text { E-MATIANT } \\
\text { [100\% } \\
{[16]}\end{array}$ & $\begin{array}{c}\text { Modified } \\
\text { Graz }\end{array}$ & $\begin{array}{c}\text { NetPower } \\
{[31]}\end{array}$ & SCOC-CC \\
\hline gCO $_{2}$ eq $/ \mathrm{kWh}$ & 19 & 366 & 21 & 29.84 & 26.1 & 8 & 25.33 \\
\hline
\end{tabular}

\subsection{Social}

With the aim of determining the social opinion related to CCS as well as the public investment in this field, the authors of this report conducted a survey which was answered by 136 people between 1761 years of age, where most of the respondents (92\%) were between 20-30 years old. Moreover, $83 \%$ of the samples are science graduates; of these $42 \%$ of the degrees are related to sustainability or environmental science. Here the sampling method is based on the convenience sampling procedure where subjects are selected because of their convenient accessibility and proximity to the researcher [59].

Although most of the respondents were science graduates, first of all a brief introduction describing the CCS process was presented in order to provide a closer picture of the topic to the respondents. The samples were not restricted only to people with a degree related with this topic and, thus, have a wider social opinion. Then, the respondents were asked some personal questions related to their 
age, their educational background and where they lived (to determine whether their proximity to a power plant affected their survey responses). The survey continued with questions regarding their previous knowledge about CCS techniques and it finished with specific enquiries about their opinion on economic investment by the government for this type of technology.

The results showed that $86 \%$ of the respondents would support government investment in CCS technologies, although if they had to choose between CCS and renewable technologies, $82 \%$ would choose the latter. From this $82 \%, 56 \%$ claimed not to have heard about CCS before.

Of the $14 \%$ who did not support investment in CCS technologies, almost half did not know anything about CCS. The rest noted that they had heard about this concept before but $80 \%$ of them were not capable of naming any specific technique.

Although $36 \%$ of the respondents had some education related to sustainability or environmental science, $37.5 \%$ of this $36 \%$ had never been told about CCS. $86 \%$ of the respondents from this $36 \%$ would prefer that the government invested in renewables instead of CCS technologies.

The answers obtained from the survey were compared to the social opinion from the literature. Thus, Van Alphen et al. [60] carried out an analysis in which they state that the social opinion should be divided into two sectors: stakeholders and general public. Stakeholders are agents who have a professional interest in CCS such as the industry, the government and the non-governmental organisations (NGOs), whereas all the other opinions are included in the general public. The authors stated that it is necessary to analyse their opinion because their perception of CCS is quite different; while the stakeholders have knowledge about CCS, the public in general does not have an a priori point of view and in many cases its responses to questionnaires are affected by the sparse information provided by the interviewers. The stakeholders' support on CCS technologies is based on five factors: safety, temporality/partiality (it should not be a permanent technique), financial stimulation, cooperation/commitment between the different parties such as government, experts and stakeholders, and open communication with the local communities [61].

All these factors are governed by two facts: renewable technologies should have priority if they can be well established, and both safety and effects should be studied thoroughly before implementing these technologies.

The survey carried out matches with the Van Alphen et al. study in two facts: the general public presents a lack of knowledge on CCS technologies; and society prefers renewable technologies rather than CCS.

In the last question of the survey, the respondents were asked to order different alternatives related to aspects that the government should take into account when investing public funding in a CCS oxypower plant. The results can be found in Figure 9. 


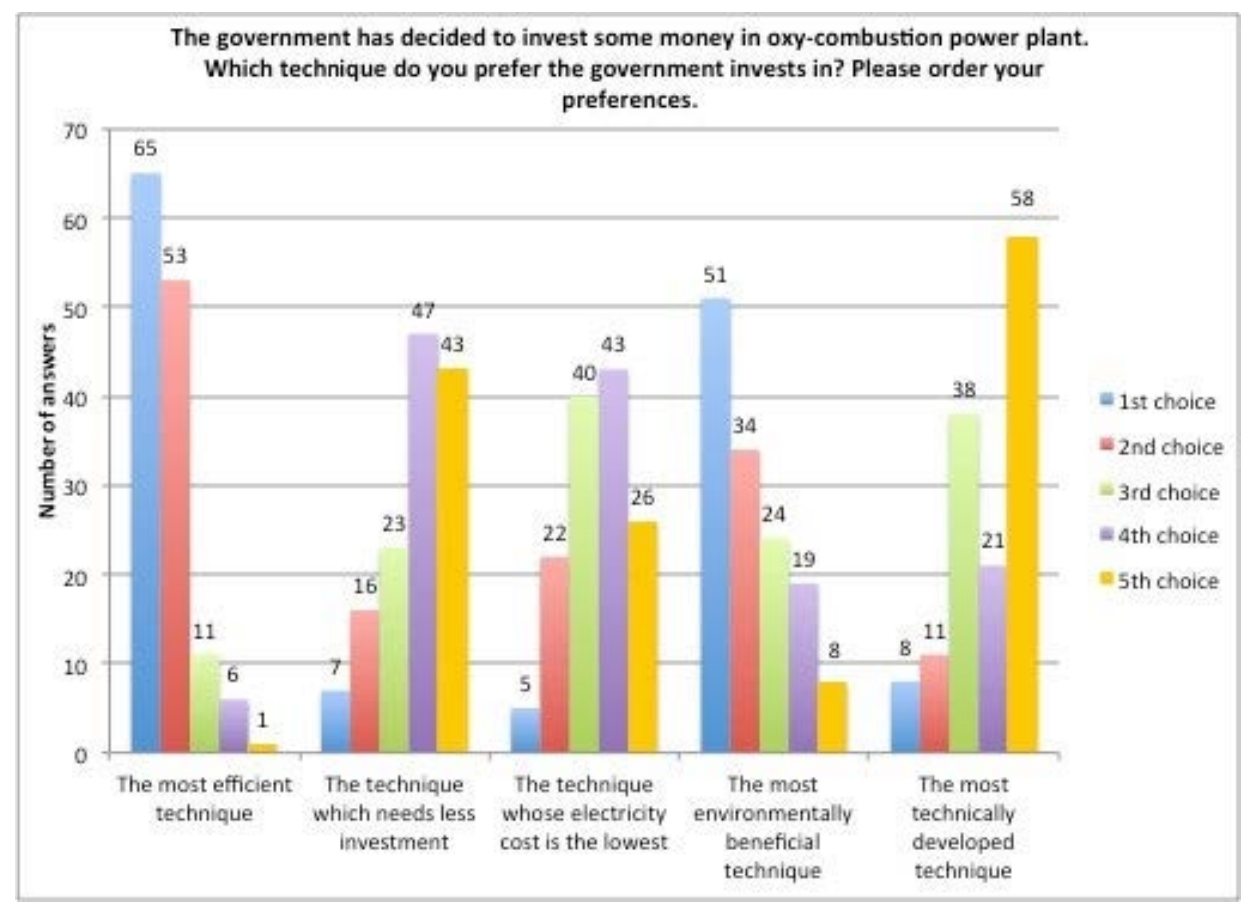

Figure 9: Responses to the last question of the survey

The social factor has been studied according to the last question of the survey. Thus, each alternative appeals to a specific cycle characteristic that can be used as a criterion to evaluate the social factor.

Hence, the importance that people gave to the different characteristics has been scored from 1 to 5 , 5 being the value attributed to the first-preferred one. This value was obtained using the equation shown below (Eq. 2), normalising it afterwards. Each one of these characteristics has been related to one of the cycle parameters obtained from the literature in order to analyse the different alternatives following an MCDA. The related parameter to each characteristic, score obtained for each factor and its respective normalised value can be observed in Table 7.

$$
\begin{aligned}
& \text { Weighted } \text { Value }_{i}=\frac{5 \times N_{i, 1}+4 \times N_{i, 2}+3 \times N_{i, 3}+2 \times N_{i, 4}+1 \times N_{i, 5}}{N_{\text {total }}} \\
& \qquad \begin{array}{l}
\mathrm{i}=\text { characteristic } \\
\mathrm{j}=1^{\text {st }}, 2^{\text {nd }}, 3^{\text {rd }}, 4^{\text {th }} \text { or } 5^{\text {th }} \text { choice } \\
\mathrm{N}_{\mathrm{i}, \mathrm{j}}=\text { Number of answers for characteristic i as choice } \mathrm{j} \\
\mathrm{N}_{\text {total }}=\text { Total number of respondents (always 136) }
\end{array}
\end{aligned}
$$


Table 7: Weighted and normalised values of each characteristic for the social factor

\begin{tabular}{lccc}
\hline Characteristic & $\begin{array}{c}\text { Related } \\
\text { Parameter }\end{array}$ & Weighted Value & $\begin{array}{c}\text { Normalised } \\
\text { Value }\end{array}$ \\
\hline The most efficient & Net efficiency & 4.29 & 0.329 \\
The one which needs less investment & CAPEX overcost & 2.24 & 0.124 \\
The one whose electricity cost is the lowest & COE overcost & 2.54 & 0.154 \\
The most environmentally beneficial & CO $_{2}$ eq & 3.74 & 0.274 \\
The most technically developed & Readiness & 2.19 & 0.119 \\
\hline
\end{tabular}

\section{Results and discussion}

When the data were entered in the DECERNS software, one cycle was ranked highest for each factor following a Multi-Criteria Decision Analysis.

\subsection{Technological}

The best performing cycle in terms of technology is, without considering the CCGT, the NetPower cycle. However, the Modified Graz cycle has a similar score to that of the NetPower. The results of the analysis can be seen in Figure 10.

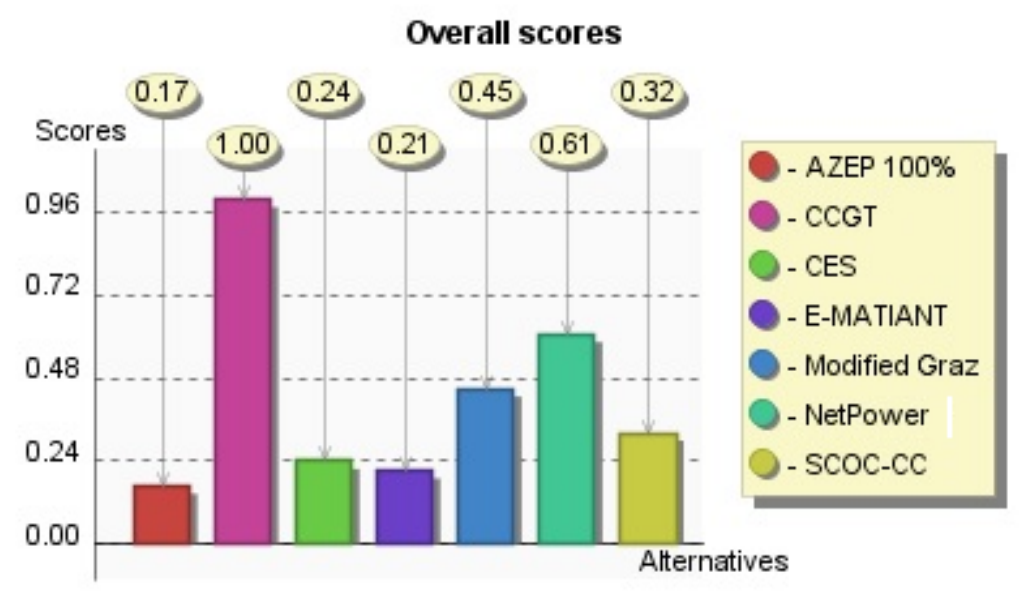

Figure 10: MCDA results for the technological factor

The Modified Graz and NetPower cycles are represented in Figure 11 and Figure 12, respectively. 


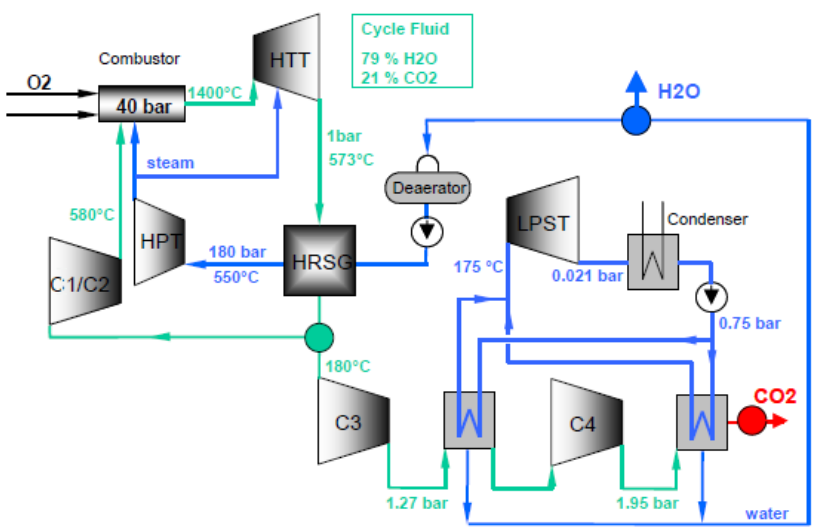

Legend: C1/C2, C3 \& C4 - Compressor, HTT - High-temperature turbine, HRSG - Heat recovery steam generator, HPT - High-pressure turbine, LPST - Low-pressure steam turbine

Figure 11: Modified Graz cycle schematic [11]

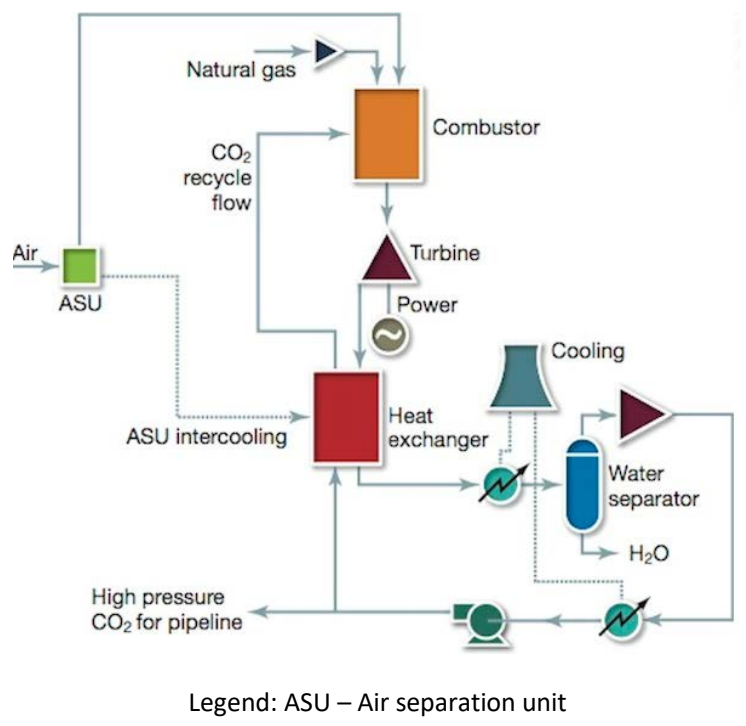

Figure 12: NetPower cycle schematic [31]

\subsection{Economic}

The most economically beneficial is, without considering the CCGT, the E-MATIANT cycle (Figure 5) followed closely by the NetPower (Figure 12). The results of this analysis can be seen in Figure 13. 


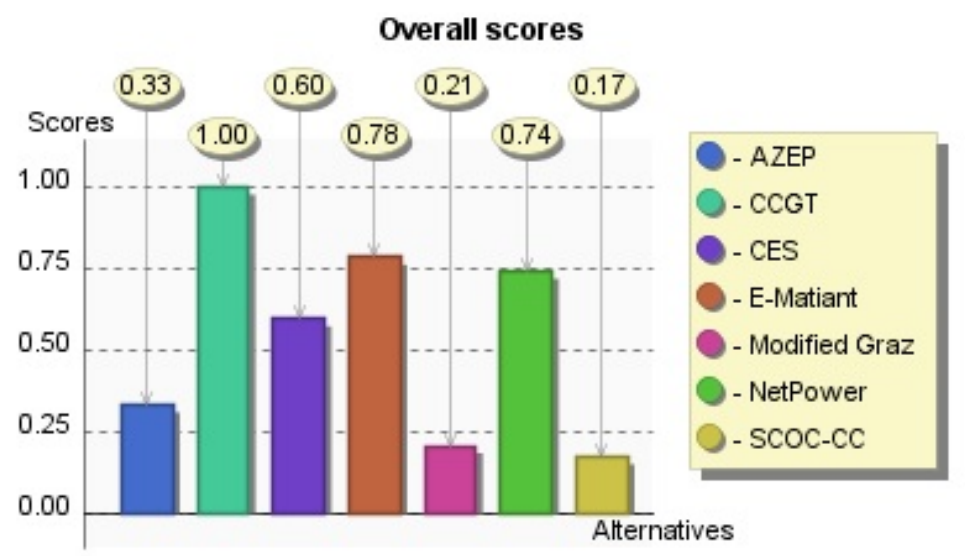

Figure 13: MCDA results for the economic factor

\subsection{Environmental}

Figure 14 shows the overall scores for the different cycles regarding their environmental benefits, meaning that the best cycle in terms of emissions is the NetPower, although the results are skewed because of the high amount of emissions released by the CCGT.

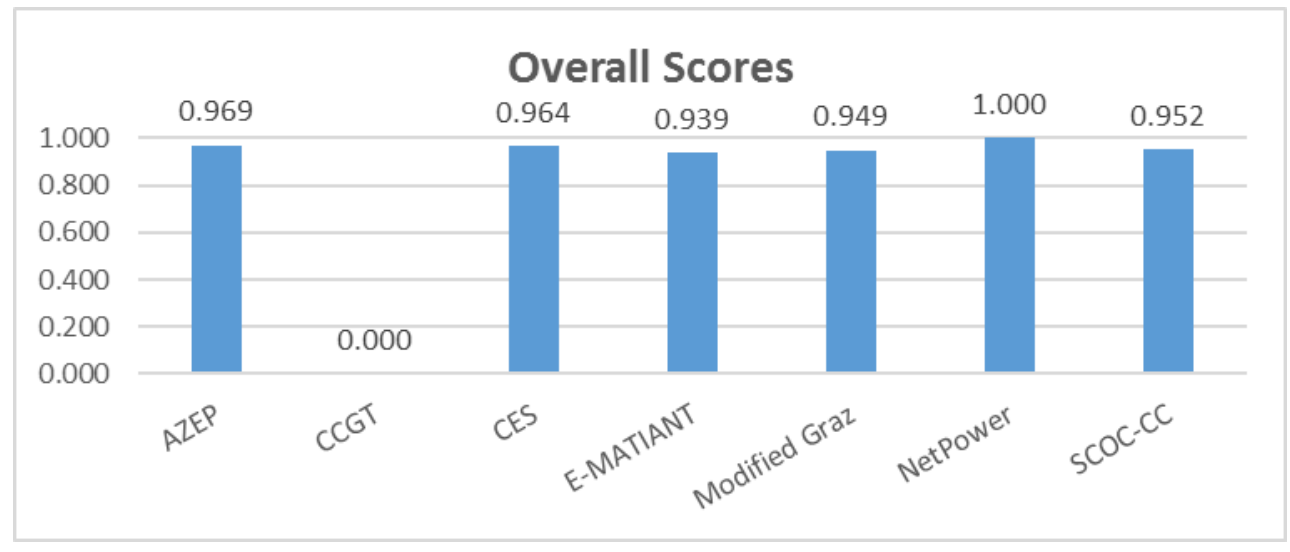

Figure 14: Results for the environmental factor

\subsection{Social}

Following the methodology explained in section 5.5, the social evaluation results are shown in Figure 15. 


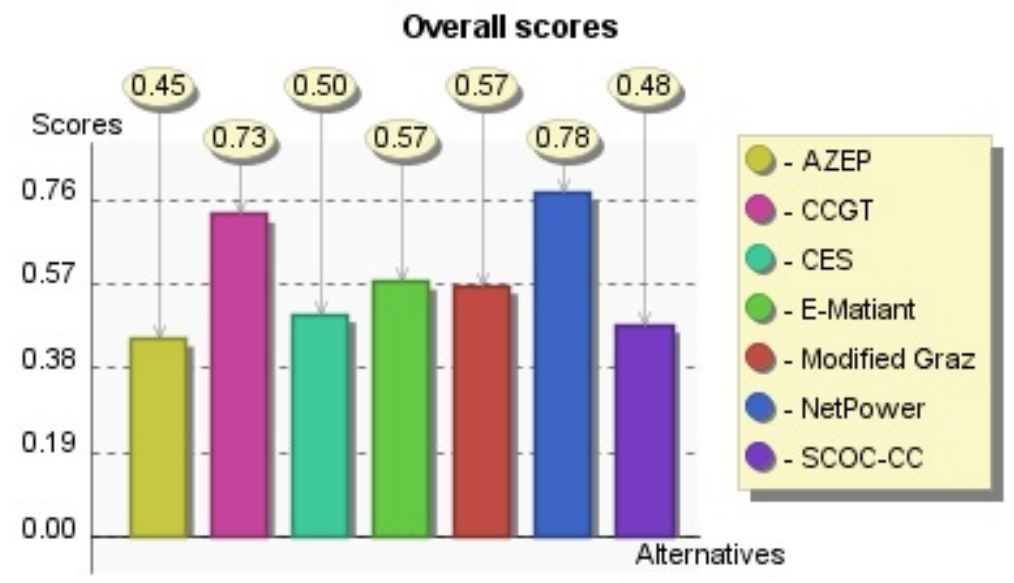

Figure 15: MCDA results for social factor

The NetPower cycle is the best solution in social terms with a higher score even than for the CCGT.

\subsection{Overall Results}

A way of summarising the results provided by the MCDA is by plotting them in a radial graph (Figure 16) where the four axes represent each of the aspects considered above.

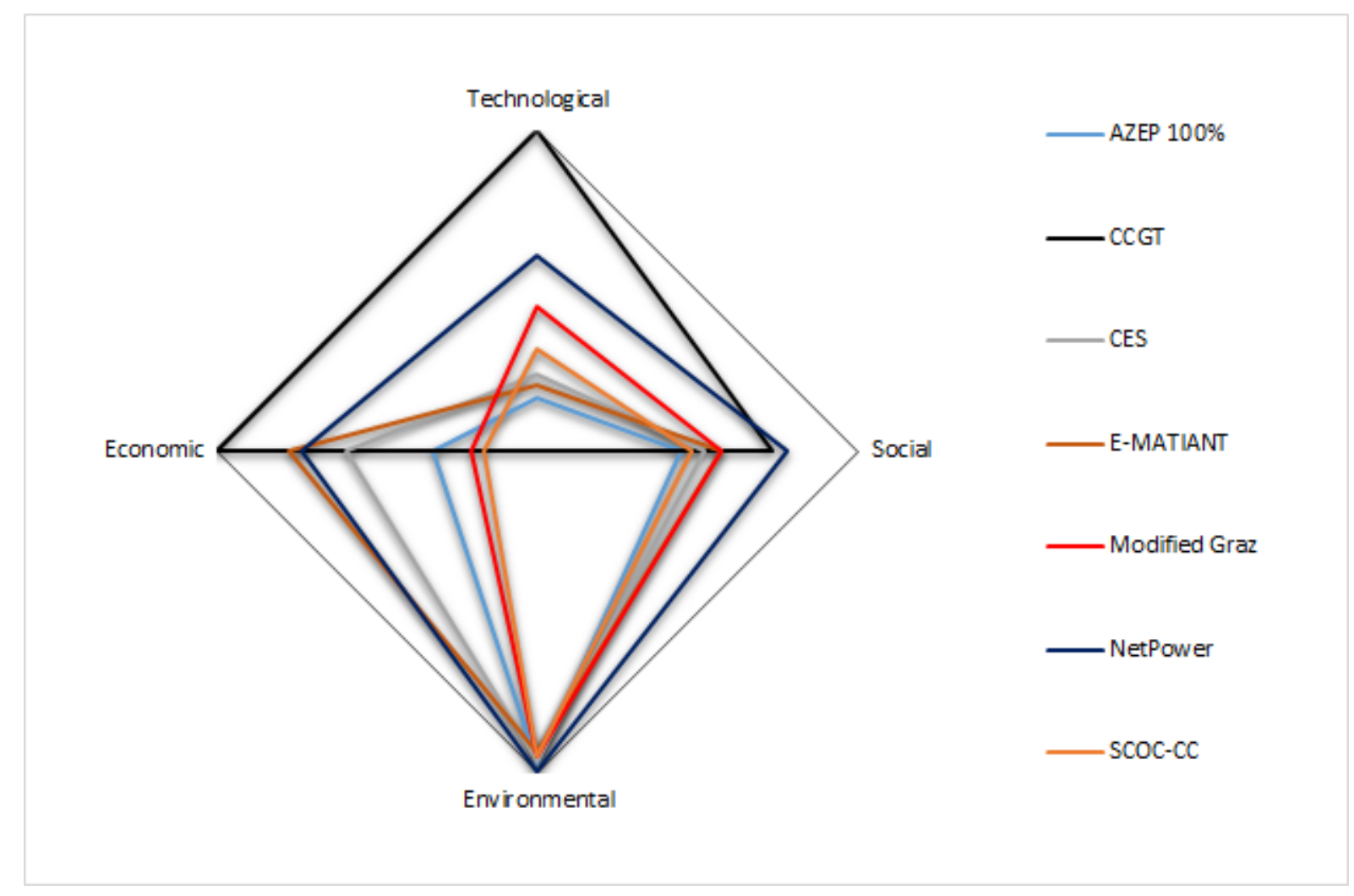

Figure 16: Radial graph of the MCDA results

When all factors are given equal weight, the NetPower is the cycle which stands out from the others, including the CCGT. The assigned weight was equal for each factor because, depending on the sector 
that analyses the scenario, the importance given to each factor would vary. Although the CCGT has the maximum score in economic and technological factors, its score of 0 in the environmental factor lowers its overall mark. Figure 17 shows the final multi-criterial results of all the cycles showing that NetPower has the best overall performance.

The NetPower cycle has a simple design offering high efficiency which provides power generation and $\mathrm{CO}_{2}$ capture with low investment and low COE. Also, if a Life Cycle Assessment is considered [31] it is the lowest in terms of $\mathrm{CO}_{2} \mathrm{e}$ emissions. The main drawback is that the thermodynamic data (e.g., LHV net efficiency) vary markedly depending on the source (company or independent researchers). However, recent publications as well as peer-review have demonstrated a more accurate value compared to past studies [52].

In order to increase the scores for the other cycles, raising them to the NetPower level, their technological and economic aspects must be improved. The adoption of political measures such as $\mathrm{CO}_{2}$ Tax and Emission Allowances could enhance the undeveloped technologies offering public funding to those technologies that still need to be supported by the government in order to be more attractive economically. However, the result of these measures would be different for each cycle. Hence, more investment by governments would increase the readiness level of cycles but other intrinsic parameters such as the efficiency or the cost in terms of materials and equipment would not vary since they depend on the complexity of the cycles themselves [61].

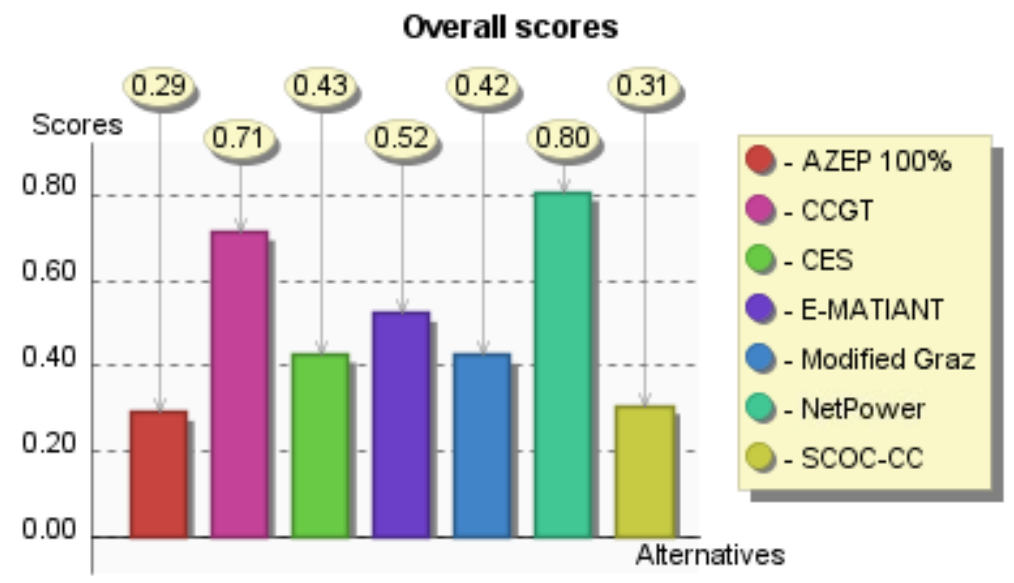

Figure 17: MCDA of the final results

\section{Conclusions}

Nineteen oxy-turbine power cycles were summarised in terms of their main characteristics and parameters, and six of these cycles were analysed. This technical review concludes most of the cycles (except CES and NetPower) are in the early development stage and mainly studied only from a thermodynamic perspective. Overall, all of the oxy-turbine cycles involve complex schemes which require technically advanced equipment but they offer high efficiencies for power generation, while at the same time, offering nearly perfect $\mathrm{CO}_{2}$ capture without generating hazardous emissions such as $\mathrm{NO}_{\mathrm{x}}$ and the best overall cycle 
efficiencies. Oxy-turbine power cycles also provide net efficiencies up to $65 \%$, comparable to a combined cycle gas turbine (CCGT) power plant (58-60 \%).

Renewable sources such as solar, biomass and biofuels have also been proposed in some oxy-turbine cycles. Generally, the application of renewable technologies in these cycles does not provide significant advantages in terms of design and efficiency. However, the benefits of renewable implementation are the reduction in fossil fuel consumption and, in the case of solar, decrease in the required oxygen supply providing this can be done without major loss of efficiency or other problems.

The PESTLE analysis has shown that from a political and legislative point of view, the oxyturbine cycles need to be supported by government measures that attract stakeholders to invest in these clean technologies. Concerning social opinion, a survey has been carried out in which 136 respondents were asked specific questions regarding CCS. Their answers show that, in general, society is unaware of the existence and requirement for these techniques, which is in agreement with previous studies on the subject. This lack of public knowledge about CCS science causes the public to favour renewable options instead of CCS technologies even when the latter are more cost effective.

From the MCDA, the NetPower cycle was identified as the best option among the oxyturbine cycles proposed for the PESTLE analysis. Further research needs to be carried out in order to demonstrate the reliability of these cycles in real industrial situations. For instance, high temperatures and flue gas composition cause an aggressive environment which implies that materials selection needs to be carefully addressed and demonstrated in trials carried out over extensive periods.

\section{Acknowledgments}

The editorial assistance of Dr David Granatstein is very much appreciated. Finally, the authors would also like to note that the first three authors have made equal contributions to this work as part of a graduate project. 


\section{References}

1. Department of Energy \& Climate Change, 2013. Greenhouse Gas Emissions, Final Figures. London, UK: National Statistics. http://www.gov.uk/government/collections/uk-greenhousegas-emissions-statistics

2. Lee, M.Y., Hashim, H., 2014. Modelling and optimization of $\mathrm{CO}_{2}$ abatement strategies. Journal of Cleaner Production, 71, pp. 40-47, doi:10.1016/j.jclepro.2014.01.005

3. Richards, G., Williams, M., 2012. Novel cycles: Oxy-combustion turbine cycles. In: Combined cycle systems for near-zero emission power generation. Ed. by A. D. Rao. Elsevier Science. Chap. 6, pp. 186-219. Available at: https://books.google.co.uk/books?isbn=0857096184

4. SCCS,2015. Global CCS Map. Available at: sccs.org.uk/expertise/global-ccs-map (Accessed: $15^{\text {th }}$ May 2015).

5. Global CCS Institute, 2013. The Callide OxyFuel Project. Available at: www.globalccsinstitute.com/insights/authors/dennisvanpuyvelde/2013/02/13/callideoxyfuel-project (Accessed: $20^{\text {th }}$ May 2015).

6. Komaki, A., Gotou, T., Uchida, T., Yamada, T., Kiga, T., Spero, C., 2014. Operation experiences of oxyfuel power plant in Callide oxyfuel project. Energy Procedia, 63, pp. 490-496, doi:10.1016/i.egypro.2014.11.053

7. ENDESA, CIUDEN, Foster Wheeler,2013. OXYCFB300 Compostilla, Carbon Capture and Storage Demonstration Project, Knowledge Sharing FEED Report Available at: http://ccsnetwork.eu/publications/oxycfb300-compostilla-carbon-capture-and-storagedemonstration-project-knowledge-sharing-feed-report (Accessed: $20^{\text {th }}$ May 2015).

8. Anderson, R.E., MacAdam, S., Viteri, F., Davies, D.O., Downs, J.P., Paliszewski, A.,2008. Adapting gas turbines to zero emission oxy-fuel power plants. Proceedings of the ASME Turbo Expo, 2, pp. 781-791, doi:10.1115/GT2008-51377

9. Allam, R.J., Palmer, M.R., Brown, G.W., Fetvedt, J., Freed, D., Nomoto, H., Itoh, M., Okita, N., Jones, C., 2013. High efficiency and low cost of electricity generation from fossil fuels while eliminating atmospheric emissions, including carbon dioxide. Energy Procedia, 37, pp. 11351149, doi:10.1016/i.egypro.2013.05.211

10. Sanz, W., Jericha, H., Moser, M., Heitmeir, F., 2005. Thermodynamic and economic investigation of an improved Graz Cycle power plant for $\mathrm{CO}_{2}$ capture. Journal of Engineering for Gas Turbines and Power, 127 (4), pp. 765-772, doi:10.1115/GT2004-53722

11. Sanz, W., Jericha, H., Bauer, B., Göttlich, E., 2007. Qualitative and quantitative comparison of two promising OXY-fuel power cycles for $\mathrm{CO}_{2}$ capture. Proceedings of the ASME Turbo Expo, 3, pp. 161-173, doi:10.1115/1.2800350

12. Mathieu, P., Nihart, R., 1999. Zero emission MATIANT cycle. American Society of Mechanical Engineers. J. Eng. Gas Turbines Power, 121 (1), pp. 116-120, doi:10.1115/1.2816297 
13. Mathieu, P., Nihart, R., 1999. Sensitivity analysis of the MATIANT cycle. Energy Conversion and Management, 40 (15), pp. 1687-1700, doi:10.1016/S0196-8904(99)00062-X

14. Mathieu, P., 2004. Towards the hydrogen era using near-zero $\mathrm{CO}_{2}$ emissions energy systems. Energy, 29 (12-15 SPEC. ISS.), pp. 1993-2002, doi:10.1016/j.energy.2004.03.007

15. Bolland, O., Kvamsdal, H.M., Boden, J.C., 2001. A thermodynamic comparison of the oxy-fuel power cycles Water-cycle, Graz-cycle and Matiant cycle. Proceedings of the International Conference POWER Generation and Sustainable Development, Association of Engineers from the Montefiore Electrical Institute (AIM), Liege, Belgium, Available at: http://www.grazcycle.tugraz.at/pdfs/Bolland Kvamsdal Boden Liege.pdf

16. Sundkvist, S. G., Klang, A., Sjödin, M., Wilhelmsen, K., Åsen, K., Tintinelli, A., McCahey, S., Ye, H., 2004. AZEP Gas Turbine Combined Cycle Power Plants-Thermal Optimisation and LCA Analysis. In Proceedings of Seventh International Conference on Greenhouse Gas Control Technologies, GHGT-7, Vancouver, Canada, doi:10.1016/B978-008044704-9/50027-6

17. Möller, B.F., Torisson, T., Assadi, M., Sundkvist, S.G., Sjödin, M., Klang, Å., Åsen, K.I., Wilhelmsen, K., 2006. AZEP gas turbine combined cycle power plants - Thermo-economic analysis. International Journal of Thermodynamics, 9 (1), pp. 21-28, Available at: http://dergipark.ulakbim.gov.tr/eoguiit//article/view/1034000164/0

18. Yantovski, E., Gorski, J., Smyth, B., Ten Elshof, J., 2004. Zero-emission fuel-fired power plants with ion transport membrane. Energy, 29 (12-15 SPEC. ISS.), pp. 2077-2088, Available at: http://doc.utwente.nl/75712/

19. Zhang, N., Lior, N., 2008. Comparative study of two low $\mathrm{CO}_{2}$ emission power generation system options with natural gas reforming. Journal of Engineering for Gas Turbines and Power, 130 (5), art. No. 051701, doi:10.1115/1.2904895

20. Zhang, N., Lior, N., 2008. Two novel oxy-fuel power cycles integrated with natural gas reforming and $\mathrm{CO}_{2}$ capture. Energy, 33 (2), pp. 340-351, doi:10.1016/j.energy.2007.09.006

21. Liu, M., Lior, N., Zhang, N., Han, W., 2008. Thermoeconomic optimization of COOLCEP-S: a novel zero- $\mathrm{CO}_{2}$-emission power cycle using LNG (liquefied natural gas) coldness. Paper IMECE 2008-66467, Proceedings of IMECE 2008, 2008 ASME international mechanical engineering congress and exposition, October 31, doi:10.1115/IMECE2008-66467

22. Gou, C., Cai, R., Hong, H., 2006. An advanced oxy-fuel power cycle with high efficiency. Proceedings of the Institution of Mechanical Engineers, Part A: Journal of Power and Energy, 220 (4), pp. 315-325, doi:10.1243/09576509JPE215

23. Cao, W., Zheng, D., 2006. Exergy regeneration in an $\mathrm{O}_{2} / \mathrm{CO}_{2}$ gas turbine cycle with chemical recuperation by $\mathrm{CO}_{2}$ reforming of methane. Energy conversion and management, 47(18), 3019-3030, doi:10.1016/i.enconman.2006.03.010

24. Zhang, N., Lior, N., 2006. Proposal and analysis of a novel zero $\mathrm{CO}_{2}$ emission cycle with liquid natural gas cryogenic exergy utilization. Journal of Engineering for Gas Turbines and Power, 128 (1), pp. 81-91., doi:10.1115/1.2031228 
25. Luo, C., Zhang, N., 2011. Zero $\mathrm{CO}_{2}$ emission SOLRGT system. Proceedings of the 24th International Conference on Efficiency, Cost, Optimization, Simulation and Environmental Impact of Energy Systems, ECOS 2011, pp. 3368-3400, doi:10.1016/j.energy.2012.04.058

26. Lu, X., 2014. Flexible Integration of the $\mathrm{sCO}_{2}$ Allam Cycle with Coal Gasification for Low-Cost, Emission-Free Electricity Generation. 8 Rivers Capital [Online] Available at: http://gasification.org/uploads/eventLibrary/2014 1128 Rivers Xijia Lu.pdf (Accessed: $25^{\text {th }}$ February 2015).

27. Sundkvist, S.G., Julsrud, S., Vigeland, B., Naas, T., Budd, M., Leistner, H., Winkler, D., 2007. Development and testing of AZEP reactor components. International Journal of Greenhouse Gas Control, 1 (2), pp. 180-187, doi:10.1016/S1750-5836(07)00025-4

28. Chase, D.L., Kehoe, P.T., GE Power Systems, Schenectady, 2010. GE Combined-Cycle Product Line and Performance. Available at: www.ger-3574g-ge-cc-product-line-performance.pdf

29. Hollis, R., Skutley, P., Ortiz, C., Varkey, V., LePage, D., Brown, B., Davies, D., Harris, M., 2012. Oxy-fuel turbomachinery development for energy intensive industrial applications. Proceedings of the ASME Turbo Expo, 3, pp. 431- 439, doi:10.1016/i.egypro.2014.11.056

30. Anderson, R., Viteri, F., Hollis, R., Keating, A., Shipper, J., Merrill, G., Schillig, C., Shinde, S., Downs, J., Davies, D., Harris, M., 2010. Oxy-fuel gas turbine, gas generator and reheat combustor technology development and demonstration. Proceedings of the ASME Turbo Expo, 3, pp. 733-743, doi:10.1115/GT2010-23001

31. Allam, R.J., 2016. NET Power's $\mathrm{CO}_{2}$ cycle: the breakthrough that CCS needs. Available at: http://www.modernpowersystems.com/features/featurenet-powers-co2-cycle-thebreakthrough-that-ccs-needs (Accessed: 12/08/2015)

32. Yang, N., Wang, R., 2015. Sustainable technologies for the reclamation of greenhouse gas $\mathrm{CO}_{2}$. Journal of Cleaner Production, 103, pp.784-792, doi:10.1016/i.jclepro.2014.10.025

33. Luu, M.J., Milani, D., Abbas, A., 2016. Analysis of $\mathrm{CO}_{2}$ utilization for methanol synthesis integrated with enhanced gas recovery. Journal of Cleaner Production, 112, pp. 3540-3554, doi:10.1016/j.jclepro.2015.10.119

34. Tak, S.H., Park,S.K., Kim, T.S., Sohn J.L., Lee, Y.D., 2010. Performance analyses of oxy-fuel power generation systems including $\mathrm{CO}_{2}$ capture: Comparison of two cycles using different recirculation fluid. Journal of Mechanical Science and Technology, 24 (9), pp. 1947-1954, Available at: http://link.springer.com/article/10.1007\%2Fs12206-010-0623-x

35. Bolland, O., Mathieu, P., 1998. Comparison of two $\mathrm{CO}_{2}$ removal options in combined cycle power plants. Energy Conversion and Management, 39 (16-18), pp. 1653-1663, doi:10.1016/S0196-8904(98)00078-8

36. Røkke, P.E., Hustad, J.E., 2005. Exhaust gas recirculation in gas turbines for reduction of $\mathrm{CO}_{2}$ emissions; Combustion testing with focus on stability and emissions, ECOS 2005 Proceedings of the 18th International Conference on Efficiency, Cost, Optimization, Simulation, and Environmental Impact of Energy Systems, pp. 1427-1434, Available at: http://dergipark.ulakbim.gov.tr/eoguijt/article/view/1034000158 
37. Soothill, C.D., Bialkowski, M.T., Guidati, G.L., Zagorskiy, A., 2013. Carbon dioxide $\left(\mathrm{CO}_{2}\right)$ capture and storage for gas turbine systems. In: Modern gas turbine systems - High efficiency, low emission, fuel flexible power generation. Ed. by P. Jansohn. Woodhead Publishing. Chap. 15, pp. 685-713. Available at:

https://books.google.es/books?id=cWREAgAAQBAJ\&printsec=frontcover\&hl=es\#v=onepage \&q\&f=false

38. Llorente, R., 2013. $\mathrm{CO}_{2}$ capture in power plants- using the oxy-combustion principle (Master's thesis, Norwegian University of Science and Technology (NTNU), Trhondeim, Norway). Retrieved from: http://www.diva-portal.org/smash/get/diva2:652833/FULLTEXT01.pdf

39. Gou, C., Cai, R., Hong, H., 2007. A novel hybrid oxy-fuel power cycle utilizing solar thermal energy. Energy, 32 (9), pp. 1707-1714, doi:10.1016/i.energy.2006.12.001

40. Kidoguchi, K., Hara, S., Oki, Y., Kajitani, S., Umemoto, S., Inumaru, J., 2011. Development of oxy-fuel IGCC system with $\mathrm{CO}_{2}$ recirculation for $\mathrm{CO}_{2}$ capture - Experimental examination on effect of gasification reaction promotion by $\mathrm{CO}_{2}$ enriched using bench scale gasifier facility. American Society of Mechanical Engineers, Power Division (Publication) POWER, 2 (1), pp. 485-492, doi:10.1115/POWER2011-55458

41. López, R., Fernández, C., Martínez, O., Sánchez, M.E., 2015. Modelling and kinetics studies of a corn-rape blend combustion in an oxy-fuel atmosphere. Bioresource Technology, 183, pp. 153-162, doi: 10.1016/j.biortech.2015.02.040

42. López, R., Fernández, C., Fierro, J., Cara, J., Martínez, O., Sánchez, M.E., 2014. Oxycombustion of corn, sunflower, rape and microalgae bioresidues and their blends from the perspective of thermogravimetric analysis. Energy, doi:10.1016/i.energy.2014.07.058

43. Beatrice, C., Di Blasio, G., Guido, C., Cannilla, C., Bonura, G., Frusteri, F., 2014. Mixture of glycerol ethers as diesel bio-derivable oxy-fuel: Impact on combustion and emissions of an automotive engine combustion system. Applied Energy, 132, pp. 236-247, doi:10.1016/j.apenergy.2014.07.006

44. Beatrice, C., Di Blasio, G., Lazzaro, M., Cannilla, C., Bonura, G., Frusteri, F., Asdrubali, F., Baldinelli, G., Presciutti, A., Fantozzi, F., Bidini, G., Bartocci, P., 2013. Technologies for energetic exploitation of biodiesel chain derived glycerol: Oxy-fuels production by catalytic conversion. Applied Energy, 102, pp. 63-71, doi:10.1016/j.apenergy.2012.08.006

45. Asdrubali, F., Cotana, F., Rossi, F., Presciutti, A., Rotili, A., Guattari, C., 2015. Life Cycle Assessment of New Oxy-Fuels from Biodiesel-Derived Glycerol. Energies, 8, 1628-1643, doi:10.3390/en8031628

46. Chen, C., Lu, Z., Ma, X., Long, J., Peng, Y., Hu, L., Lu, Q., 2013. Oxy-fuel combustion characteristics and kinetics of microalgae Chlorella vulgaris by thermogravimetric analysis. Bioresource Technology, 144, pp. 563-571, doi:10.1016/j.biortech.2013.07.011 
47. ToughNickel, 2016. What are the driving forces of PESTLE analysis? Available at http://dommcg.hubpages.com/hub/What-is-PESTLE-analysis (Accessed on 26/05/2016)

48. Sullivan, T., Yatsalo, B. I., Grebenkov, A., Linkov, I., 2009. Decision Evaluation for Complex Risk Network Systems (DECERNS) Software Tool, Chapter 12, pp. 257-274, Springer Book, Decision Support Systems for Risk-Based Management of Contaminated Sites, Available at: http://link.springer.com/chapter/10.1007/978-0-387-09722-0 12\#page-1

49. Chalmers, H., Gibbins, J., 2010. Carbon capture and storage: The ten year challenge. Proceedings of the Institution of Mechanical Engineers, Part C: Journal of Mechanical Engineering Science, 224 (3), pp. 505-518, doi: 10.1243/09544062JMES1516

50. Chalmers, H., Gibbins, J., Lucquiaud, M., 2009. Retrofitting $\mathrm{CO}_{2}$ capture to existing power plants as a fast track mitigation strategy. In ASME 2009 3rd International Conference on Energy Sustainability collocated with the Heat Transfer and InterPACK09 Conferences (pp. 669-678). American Society of Mechanical Engineers, doi:10.1115/ES2009-90401

51. U. S. Department of Defence, 2011. Technology Readiness Assessment (TRA) Guidance, revision posted 13 May 2011. [Online] Available at: http://www.acq.osd.mil/chieftechnologist/publications/docs/TRA2011.pdf (Accessed: $20^{\text {th }}$ May 2015).

52. IEAGHG, 2015. Oxy-combustion turbine power plants, Report 2015/05, Available at: http://ieaghg.org/terms-of-use/49-publications/technical-reports/599-2015-05-oxycombustion-turbine-power-plants

53. Yang, H.J., Kang, D.W., Ahn, J.H., Kim, T.S., 2012. Evaluation of Design Performance of the Semi-Closed Oxy-Fuel Combustion Combined Cycle. ASME. J. Eng. Gas Turbines Power, 134 (11), pp. 111702-111702-10. doi:10.1115/1.4007322

54. Franco, F., Mina, T., Woolatt, G., Rost, M. and Bolland, O., 2006, June. Characteristics of cycle components for $\mathrm{CO}_{2}$ capture. In Proceedings of 8th International Conference on Greenhouse Gas Control Technologies, Trondheim, Norway, Available at:

http://www.graz-cycle.tugraz.at/pdfs/franco et al ghg 2006.pdf

55. Anderson, R.E., Brandt, H., Mueggenburg, H., Taylor, J., Viteri, F., 1998. A power plant concept which minimizes the cost of carbon dioxide sequestration and eliminates the emission of atmospheric pollutants. Fourth International Conference of Greenhouse Gas Technologies. Interlaken, Switzerland, Available at: http://www.co2.no/download.asp?DAFID=30\&DAAID =4

56. Houyou, S., Mathieu, P., Nihart, R., 2000. Techno-economic comparison of different options of very low $\mathrm{CO}_{2}$ emission technologies. In Proceedings of the Fifth International Conference on Greenhouse Gas Control Technologies (p. 1003), Available at: https://books.google.es/books?isbn $=0643066721$

57. Spath, P., Mann, M., 2000. Life Cycle Assessment of a Natural Gas Combined-Cycle Power Generation System. NREL/TP-570-27715 [Online] Available at: http://www.nrel.gov/docs/fy00osti/27715.pdf(Accessed: $5^{\text {th }}$ May 2015). 
58. Lombardi, L., 2003. Life cycle assessment comparison of technical solutions for $\mathrm{CO}_{2}$ emissions reduction in power generation. Energy Conversion and Management, 44 (1), pp. 93-108, doi:10.1016/S0196-8904(02)00049-3

59. Peterson, R. A., Merunka, D. R., 2014. Convenience samples of college students and research reproducibility. Journal of Business Research, 67(5), pp. 1035-1041, doi:10.1016/j.jbusres.2013.08.010

60. Van Alphen, K., Tot Voorst, Q. V. V., Hekkert, M. P., Smits, R. E., 2007. Societal acceptance of carbon capture and storage technologies. Energy Policy, 35(8), pp. 4368-4380, doi:10.1016/i.jbusres.2013.08.010

61. Wennersten, R., Sun Q., Li, H., 2015. The future potential for Carbon Capture and Storage in climate change mitigation - an overview from perspectives of technology, economy and risk. Journal of Cleaner Production, 103, pp. 724-736, doi:10.1016/.jclepro.2014.09.023 